\title{
Technological Considerations in Emergency Instrumentation Preparedness
}

\author{
Phase II-C - Emergency Radiological \\ and Meteorological \\ Instrumentation for Fuel \\ Reprocessing Facilities
}

August 1976

Prepared for the Energy Research and Development Administration under Contract E(45-1)-1830 
NOTICE

This report was prepared as an account of work sponsored by the United States Government. Neither the United States nor the Energy Research and Development Administration, nor any of their employees, nor any of their contractors, subcontractors, or their employees, makes any warranty, express or implied, or assumes any legal liability or responsibility for the accuracy, campleteness or usefulness of any imformation, apparatus, product or process disclosed, or represents that its use would not infringe privately owned rights.

\author{
PACIFIC NORTHWEST LABORATORY \\ operated by \\ BATTELLE \\ for the \\ ENERGY RESEARCH AND DEVELOPMENT ADMINISTRATION \\ Under Contract E(45-1)-1830
}

Printed in the United States of America

Available from

National Technical Information Service

U.S. Department of Commerce

5285 Port Royal Road

Springfield, Virginia 22151

Price: Printed Copy \$5.50; Microfiche \$2.25 
Phase II-C - Emergency Radiological and Meteorological Instrumentation for Fuel Reprocessing Facilities
B. V. Andersen
L. A. Carter
J. G. Droppo
J. Mishima
L. C. Schwendiman
J. M. Selby
R. I. Smith
C. M. Unruh
D. A. Waite
E. C. Watson
L. D. Williams

August 1976

Battelle

Pacific Northwest Laboratories

Richland, Washington 99352 
BNWL-1857

FOREWORD

The Energy Research and Development Administration, through its Division of Safety, Standards and Compliance, has contracted with Battelle, Pacific Northwest Laboratories, to conduct a study and develop technical criteria for determining the adequacy of instrumentation for use in radiological emergencies, abnormal occurrences and accidents. The program is responsive that emergency instrumentation criteria be developed and that nuclear facilities establish a capability to cope with a serious accident. The work has been progressing in close collaboration with the Nuclear Regulatory Commission. A technical steering committee was established comprising representation from the Division of Safety, Standards and Compliance, the Reactor Research and Development Division, the Nuclear Regulatory Commission, ERDA-RL, Environmental and Laboratory Programs Division, and the Environmental Protection Agency. This committee provides surveillance and technical direction and assures that the overall needs of the program and associated objectives are met. As a first step, the current practices at a number of ERDA and licensed facilities were reviewed. Results of the review were approved and reported in BNWL-1552, "Technological Considerations in Emergency Instrument Preparedness, Phase I - Current Capabilities Survey." A summary of emergency instrumentation criteria for reactors was presented in the Phase II-A report, BNWL-1635. BNWL-1742 provided a summary of emergency instrumentation criteria for mixed oxide fuel fabrication facilities which was developed during the second portion of the Phase II study. This report, BNWL-1857, reviews emergency instrumentation criteria for fue 1 reprocessing facilities.

E. J. Vallario, Chairman ERDA Headquarters Battelle-Northwest Project Steering Committee

M. B. Biles, Director

Division of Safety, Standards and Compliance 


\section{CONTENTS}

FOREWORD

I. INTRODUCTION .

II. SCOPE AND OBJECTIVES

III. SUMMARY AND CONCLUSIONS . . . . . . . . . . . . . . . . . . . . . 2

IV. THE FUEL REPROCESSING FACILITY ACCIDENT POTENTIAL. . . . . . 3

1. The Reference Plant and Process . . . . . . . . . . 5

2. Accident Characteristics and Source Terms . . . . . . . 9

1. Nuclear Criticality Event . . . . . . . . . . . 9

2. Explosion in High Activity Waste (HAW) Concentrator . . 11

3. Fire Involving the Plutonium Product Solution System . . 16

4. Release of Radioiodine From the Dissolver Off-Gas System. 16

5. A Fire in the Solvent Extraction System . . . . . . 16

6. Processing of Freshly Discharged Fuel . . . . . . 17

3. Summary of Accident Source Terms . . . . . . . . . 17

V. EMERGENCY INSTRUMENTATION REQUIREMENTS . . . . . . . . . . 19

1. Criticality Instrumentation. . . . . . . . . . . . 20

2. Stack Effluent Monitor . . . . . . . . . . . 21

3. Ambient Radiation Measurements. . . . . . . . . . . 21

4. Determination of the Magnitude and Trajectory of the Plume . 22

5. Radiological Measurements in the Environs. . . . . . . 24

6. Portable Instrumentation. . . . . . . . . . . . . 25

VI. PERFORMANCE CRITERIA FOR EMERGENCY INSTRUMENTATION . . . . . 26

1. Criticality Detection and Alarm System . . . . . . . . . 26

1. Criticality Detection and Alarm System Performance Criteria . . . . . . . . . . . . . . . . 27

2. Instrumentation Performance Criteria . . . . . . 29 
BNWL-1857

2. Radiological Instrumentation . . . . . . . . . . . 30

1. Installed Radiological Instrumentation. . . . . . 31

1. Systems Performance Criteria. . . . . . . . . 33

2. Performance Criteria for

Air Concentration Level Instrumentation. . . . . 34

3. Performance Criteria for Ambient Radiation Instrumentation . . . . . . . . . . . . . 35

2. Transportable Radiation and Contamination

Mea surement Instrumentation . . . . . . . . . . 36

1. Transportable Instrumentation Systems Performance Requirements . . . . . . . . . . . . . . 37

2. Performance Criteria for Transportable Dose Rate and Contamination Survey Instrument. . . . . . . . 40

3. Airborne Particulate Monitoring . . . . . . . . . 45

1. Sampling of Aerosol . . . . . . . . . . . . . 46

2. Measurement of Accident Stack Release. . . . . . 46

3. Stack Monitor Performance Criteria. . . . . . . 48

4. Environmental Air Monitoring . . . . . . . . . . 50

1. Transportable Air Monitoring Systems . . . . . . 52

2. Environmental Air Monitor Performance Criteria. . . 53

5. Personnel Dosimeters. . . . . . . . . . . . . 55

1. Personnel Dosimeters Performance Criteria . . . . 56

2. Alarming Dosimeters . . . . . . . . . . . 57

3. Meteorological Instrumentation. . . . . . . . . . . 58

1. Meteorological Data Requirements. . . . . . . . . 58

2. Performance Criteria for Meteorological Systems. . . . 61 
BNWL - 1857

\section{FIGURES}

Page

1. Fuel Reprocessing Facilities Emergency Instrumentation Systems

2. Longitudinal Cross-Section of a Typical Fuel Reprocessing Plant

3. Process Flow Diagram

4. Release Rate, $R(t)$, and Accumulated Release, $C_{(t)}$, Assuming Five Cel1 Air Changes per Hour, Norma tized to an Initial Concentration in the Cell of Unity

\section{TABLES}

1. Process Equipment Fission Product Inventory 10

2. Source Terms for Head-End Criticality Accident 13

3. Fission Product Activity Inventory in the HAWC 15

4. Potential Releases and Initial Rates of Release From Various Postulated Accident Scenarios

5. Routine and Accident Stack Concentrations

6. Examples of Atmospheric Diffusion Models and Their Required Inputs 
TECHNOLOGICAL CONSIDERATIONS

IN EMERGENCY INSTRUMENTATION PREPAREDNESS

\author{
Phase II-C - Emergency Radiological and Meteorological \\ Instrumentation for Fuel Reprocessing \\ Facilities
}

\title{
I. INTRODUCTION
}

In response to recommendations from the Advisory Committee on Reactor Safeguards, the Division of Safety, Standards and Compliance, USERDA, has contracted with Battelle, Pacific Northwest Laboratories, to survey the adequacy of existing instrumentation at nuclear fuel cycle facilities to meet emergency requirements, and to develop technical criteria for instrumentation systems to be used in assessment of envirormental conditions following plant emergencies. The technical criteria for emergency instrumentation systems are derived in part from the accident parameters which these systems must detect.

Only three fuel reprocessing facilities--Nuclear Fuel Service, Inc., Spent Fuel Reprocessing Plant; General Electric Company, Midwest Fuel Recovery Plant; Allied Gulf Nuclear Services, Inc., Barnwell Nuclear Fuel Plant--have been designed, and much of the information on accident conditions used in this study are generalizations and extensions of accidents extracted from their final Safety Analysis Reports. With the exception of reprocessing of LMFBR fuel, which contains a higher enrichment of plutonium than the reference case for this document (note Section IV, pp 5 and 7), the criteria contained herein are generally applicable to all fuel reprocessing facilities.

Some maximum conditions for performance of instrumentation are developed by using conservative assumptions in the definitions of the source terms. In the final analysis the derived values are only meant to be used in defining instrument performance criteria.

This report, the fourth in series, presents a set of performance standards for instrumentation and instrumentation systems to aid in making real time judgments about the radiological consequences of inadvertent releases of 
activity from commercial fuel reprocessing plants. The previous reports in this series presented the results of a survey of existing emergency instrumentation throughout the industry $(1)$ and examined these needs for power reactors $(2)$ and mixed oxide fuel fabrication plants. (3)

\section{SCOPE AND OBJECTIVES}

The scope and objectives of this study are to recommend technical performance criteria for emergency sensitive instrumentation capable of detecting and measuring the potentially large releases from the plant under any of the postulated accident conditions in order to make action decisions in real-time easier. Accomplishment of these objectives requires a review of the structure of the facility, the various processes and equipment in use, and types and quantities of materials in process, the range of potantial accidents and accompanying releases of radioactive material to the environs, the modes of dispersion and deposition of the radioactive materials outside of the facility, and the identification of appropriate instrumentation capability.

\section{SUMMARY AND CONCLUSIONS}

A reference fuel reprocessing plant, postulated to process fuels from light water reactors with initial enrichments less than $5 \%{ }^{235} \mathrm{U}$ or equivalent fissile content, with exposures in the vicinity of 40,000 MWd/MTU and cooling times of approximately 150 days, was used to determine the sources and magnitudes of radionuclide releases to the environment in the event of postulated accidents within the plant. Based on these estimates of accident generated conditions, performance criteria were developed for instrumentation systems to 1) immediately detect the occurrence of a release, 2) determine the magnitude and direction taken by the release, and 3) permit estimation of the impact of the release on the environs of the plant.

An inspection of the assumed inventory of radionuclides in various areas of the reference plant shows that the areas of maximum potential release are the head-end tanks and the High Activity Waste (HAW) handiing systems. In those particular areas the accidents that could produce the largest releases 
are a nuclear criticality event and an explosion in the HAW concentrator, respectively. Other events considered include a fire involving the plutonium product system, a fire involving the solvent extraction system, an overheating of the caustic scrubber solutions, and the processing of freshly discharged fuel. These accidents were selected to include release mechanisms for the different types of radionuclides present, i.e., plutonium, mixed fission products and radioiodines. Since the reference plant structure was assumed to withstand the stresses imposed by most natural phenomena, an accident which would destroy the building would be highly improbable. Direct measurement of the releases occurring in a major breach of the plant confinement barrier presently is not feasible; hence, calculation of the dispersion of material outside the plant is dependent on meteorological parameter instrumentation and potential release terms estimations. Measurements of releases under postulated accident conditions are apparently best accomplished by using monitoring systems on the ventilation stack. Portable survey equipment would verify or refine the predictions made using the environmental dispersion calculations.

Typical emergency instrumentation and instrumentation systems (shown in Figure 1) for fuel reprocessing facilities could consist of:

- In-facility criticality detection

- Effluent monitoring of stack released mixed fission products

- Fixed environmental stations for collecting particulates

- Fixed environmental stations for telemetering direct radiation levels

- Portable instrumentation for dose rate measurements.

\section{THE FUEL REPROCESSING FACILITY ACCIDENT POTENTIAL}

"Standard" accidents, such as those defined for reactors in a proposed annex to Appendix D of 10 CFR Part 50, ${ }^{(4)}$ have not been well developed for fuel reprocessing facilities. However, design basis accidents have been postulated in Safety Analys is Reports (SAR) on three present generation reprocessing plants, Midwest Fuel Reprocessing Plant, ${ }^{(5)}$ Barnwe 11 Nuclear Fuel Plant, ${ }^{(6)}$ and NFS Fuel Reprocessing Plant. (7) These have been reviewed to identify areas in a reprocessing plant where an accident may result in large activity releases. 


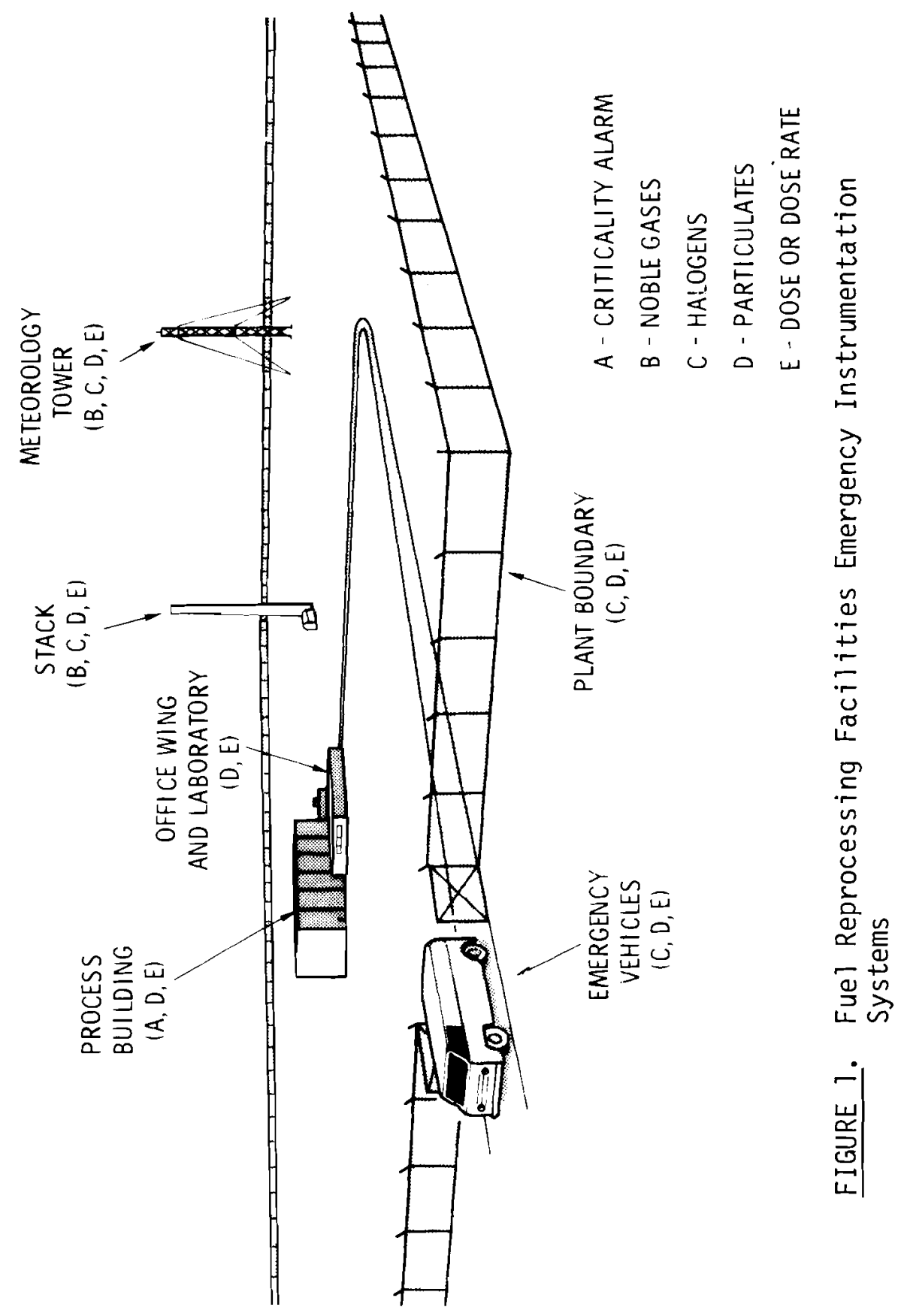


The source terms used here are limited to airborne releases. Releases of radioactive material via liquid media are not considered an immediate emergency problem. No liquid effluent release parameters were postulated which resulted in dose pathways in the environment which were of immediate emergency significance. The high-level liquid waste is considered a major source of potential airborne release under postulated accidents but is not a significant accident potential as a liquid waste release to the environs.

\section{1 THE REFERENCE PLANT AND PROCESS}

The guidance on measurement ranges for the emergency instrumentation is influenced by the amounts of material conceivably available for release. Any of the suggested release parameters may need modification for application to a specific facility because of variations in processes, equipment and inventory.

For purposes of this study, a reference plant designed for processing irradiated fuels from light water power reactors (LWR) is assumed. [A crosssection diagram for such a plant is shown in Figure 2. (8) ] Further assumptions of the plant's design are:

- The plant processes fuel with initial enrichments 1 ess than $5 \%{ }^{235} \mathrm{U}$ or equivalent fissile content with exposures around 40,000 MWd/MTU and cooling times of 2150 days.

- Plant buildings are designed as Seismic Category I structures capable of withstanding any earthquake, tornado or other nature disaster likely to occur in that locality.

- Within the plant buildings, which serve as the final confinement barrier, the radioactive materials are contained within piping and tankage systems in process cells.

- Process streams are highly compartmentalized such that an accident in one cell would not create a problem in adjacent cells.

- Caustic scrubbers and silver-zeolite absorber beds remove radionuclides from the off-gas system (dissolver off-gas and vessel vent). 


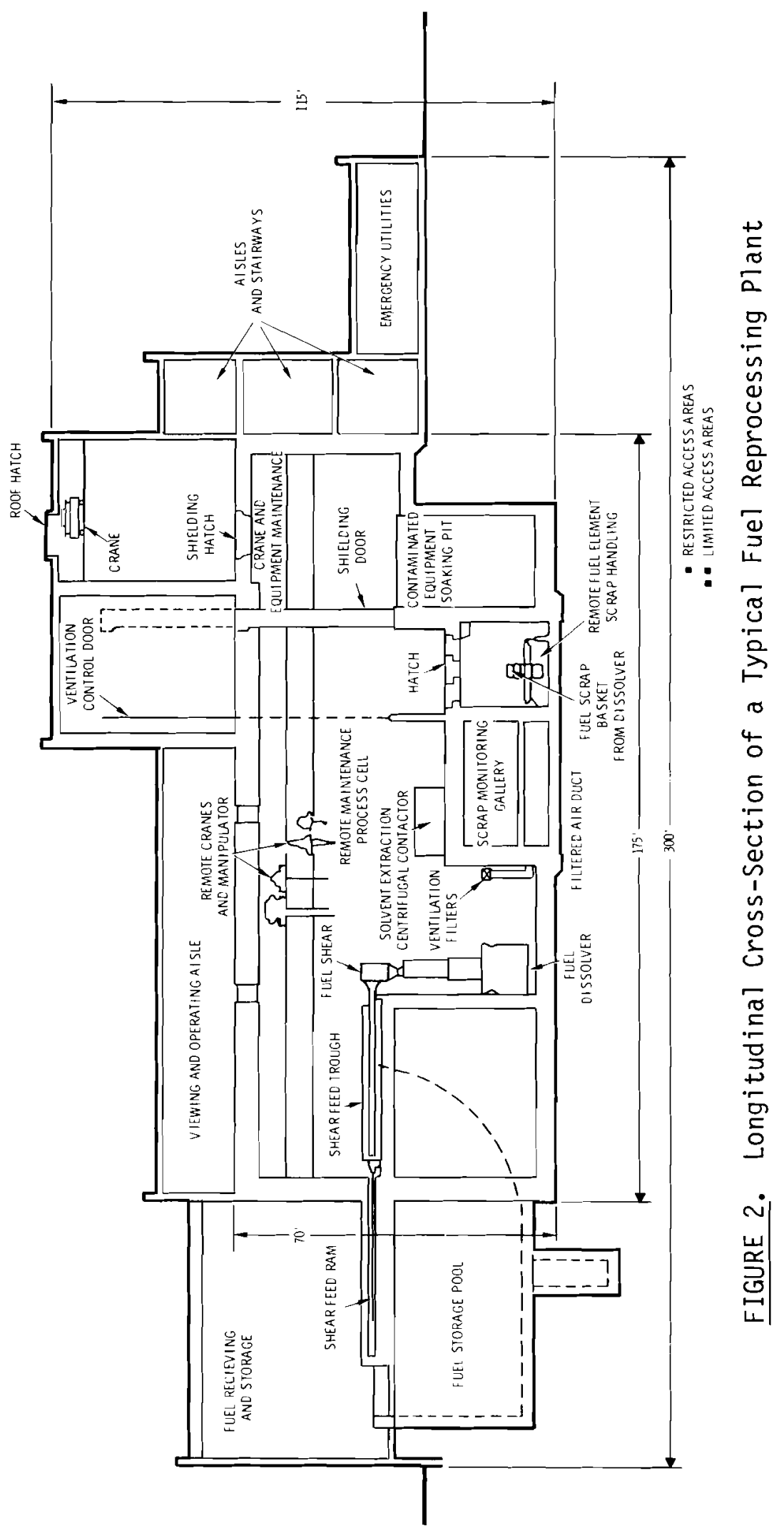


- All potentially contaminated air passes through several steps of filtration including either HEPA or deep-bed sand or fiberglass final filters before discharge from the $100 \mathrm{~m}$ stack.

Several factors may reduce the potential release inventory of a specific plant from those values selected for consideration here. Two of these factors are: 1) differences in chemical or physical form of released contaminants and 2) additional criticality safety limitations.

The plant uses a chop and leach system for fuel element disassembly and dissolution. A "Purex" type solvent extraction process is used for separation of fission products from fuel products (uranium, plutonium, neptunium) and for separation of uranium and neptunium from plutonium. The high activity waste (HAW) is concentrated and solidified for local interim storage. The product plutonium is reduced to a solid form for shipment; the recovered uranium is converted to $U_{6}$ for shipment. (A simplified flow diagram of the model process is shown in Figure 3.)

After an interim storage period of 2150 days to permit short-life radionuclides to decay, the fuel elements are chopped into short pieces which expose the metal oxides. The metal oxides are leached by hot nitric acid, leaving behind the chopped tubing (hulls). The hulls are soaked in hot nitric acid and then washed in water to assure that essentially all of the nuclear material has been removed. The nitric acid solution, containing the special nuclear material and fission products, is adjusted chemically and processed through solvent extraction systems which separate the fission products, the uranium, and the plutonium from each other. The purified uranium is recycled back to the nuclear power reactors as replacement fuel elements. The purified plutonium product is stored for an interim period pending conversion to $\mathrm{PuO}_{2}$ for use in plutonium recycle or breeder reactor fuel elements.

Nitric acid recovered during the concentration of the high-level and low-level waste is reused in the process. The concentrated high-level and low-level waste is stored in stainless steel storage tanks located in underground concrete vaults. Within 5 years after being produced, this liquid highlevel waste is solidified and then transferred, within 10 years, to a Federal repository for long-term storage. 


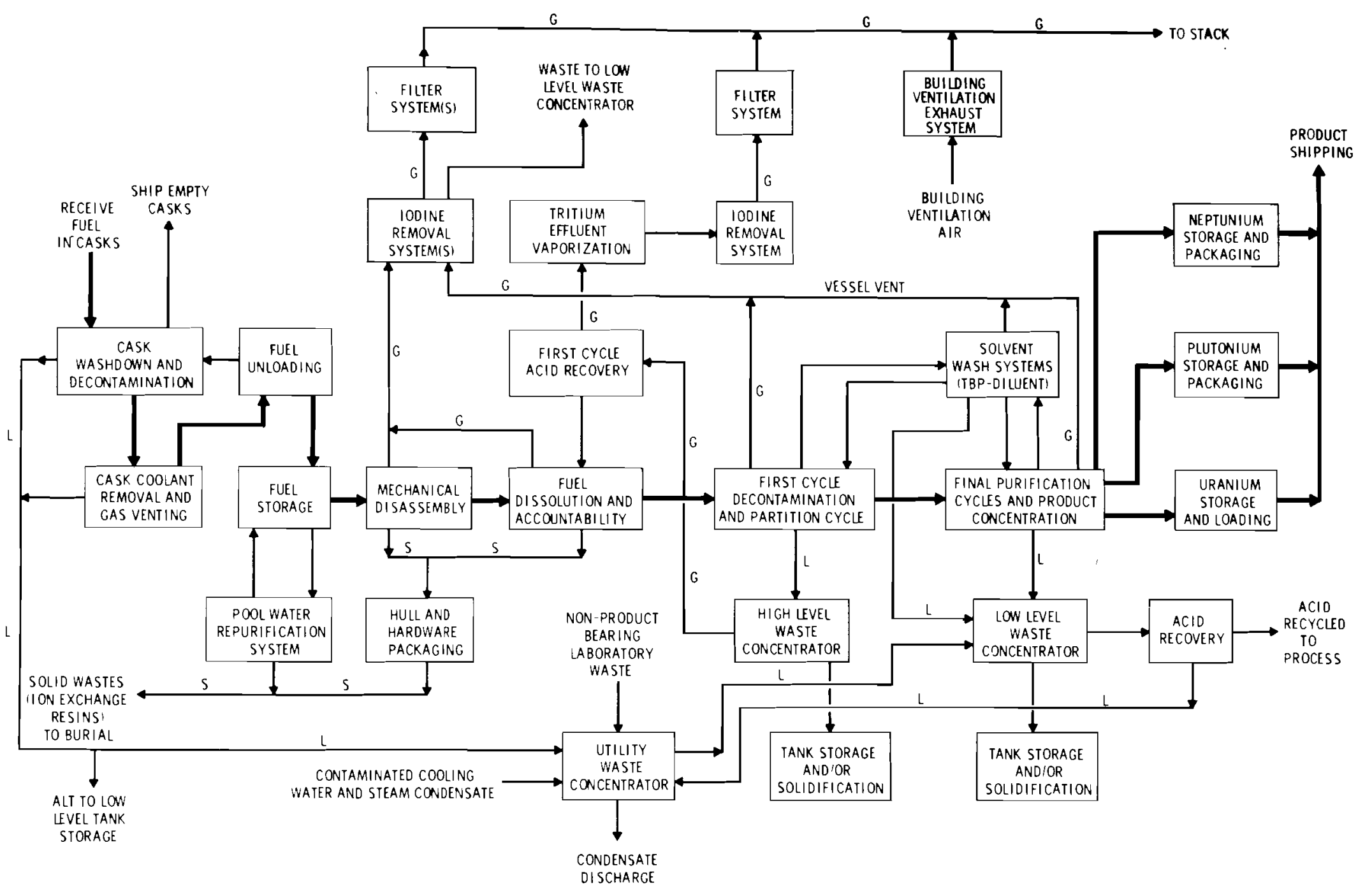

- RAIN PRODUCT STREAM

- PROCESS STREAM

-S- SOLIO WASTE

- L- LIQUID WASTE

- G- gaseous EFFLUENT 
The fission product inventories in the various portions of the process equipment are identified in Table 1, abstracted from Reference 5 which 1 ists the approximate number of curies of radioactive material per design basis tonne of throughput present throughout the process stream.

\section{IV.2 ACCIDENT CHARACTERISTICS AND SOURCE TERMS}

For the reference plant the areas of maximum potential release are in the head-end tanks and in the High Activity Waste (HAW) handling system. In those particular areas, the accidents that may produce the largest releases are a nuclear criticality event and an explosion in the HAW concentrator, respectively. Other events considered include a fire involving the plutonium product system, a fire involving the solvent extraction system, an overheating of the caustic scrubber solutions, and the inadvertent processing of irradiated fuel stored less than 150 days. These accidents were selected to encompass release mechanisms for the different types of radionuclides involved, i.e., plutonium, mixed fission products, and radioiodines. Each of these postulated events is discussed separately in the following sections.

\section{IV.2.1 Nuclear Criticality Event}

For the purposes of this study, a "worst case" type of nuclear excursion is postulated--a criticality in a head-end vessel of maximum capacity. The principal cause of most of the reported nuclear excursions involving liquid solution was the inadvertent use of nongeometrically safe vessels. $(9,10)$ such human error cannot be absolutely eliminated in the operating lives of future reprocessing facilities. Since the size and configuration of all such vessels is not known, actions or mechanism that may terminate such an excursion cannot be postulated. Thus the conditions which could result in the largest airborne release of radionuclides were assumed to be operative.

The following assumptions were used to arrive at a release value:

- Criticality results in $4 \times 10^{19}$ fissions.

- The off-gas line fails. This was assumed in order to maximize the potential release. 
TABLE 1. Process Equipment Fission Product Inventory (5)

(Per design basis tonne of throughput)

\section{Equipment}

1. Leacher

2. Leacher Reservoir

3. HAF Tank

4. HA Column

5. HC Column

6. HCU Concentrator ( $\mathrm{Zr}, \mathrm{Nb}, \mathrm{Ru}) \quad 47$ and Stripper (A11 Others) 11

7. Pu Anion Exchange Unit

49

8. NP Valence Adjust- ( $\mathrm{Zr}, \mathrm{Nb}, \mathrm{Ru}) \quad 47$ ment Tank

(A11 Others)

9. NP Anion Exchange Unit 49

10. UNH Concentrator ( $\mathrm{Zr}, \mathrm{Nb}, \mathrm{Ru})$ and Fractionator (A11 Others)

20

4.7

11. UNH Calciner ( $r r, \mathrm{Nb}, \mathrm{Ru})$

490

12. Fluorinator

(Zr)
(Nb, Ru)
(A11 Others

1940

$2.2 \times 10^{3}$

13. NaF Sorption Bed (Ru)

$1.1 \times 10^{4}$

14. UF 6 Distiliation (Ru)

$1.6 \times 10^{4}$

15. HAW Concentrator and Fractionator

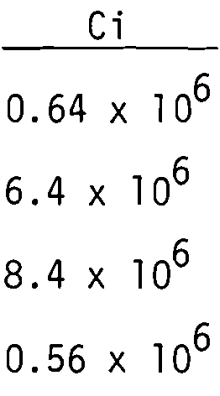

61

1

9

Equipment

16. HAWC Sample Tank

17. HAWC Calciner

18. HAW Calciner

19. High Level Waste Accumulator

20. High Level Acid Tank

21. $\underset{T a n k}{\text { Organic Storage (Ru) }}$ (A11 0thers)

22. Low Level Waste Accumulator

23. Low Level Waste Concentrator

24. Recycle Water Tank

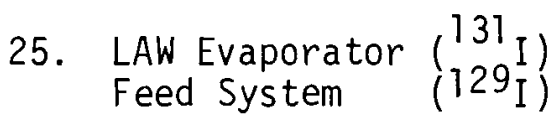

26. LAW Evaporator ( $\left.\begin{array}{l}131 \\ 129\end{array}\right)$ (A11 Others) 27.
Process vent
Scrubber (A11 Others)

28. Low Level Acid (Ru) Tank (A11 Others)

29. Silver Reactor $\left(\begin{array}{l}131 \\ 129\end{array}\right.$

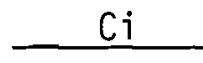

$6.7 \times 10^{5}$

$6.7 \times 10^{6}$

$2.7 \times 10^{6}$

$2.7 \times 10^{7}$ (Max.)

\section{0}

680

8.4

5.9

$6.7 \times 10^{3}$

$1.3 \times 10^{4}$

2

$1.0 \times 10^{-3}$
$1.1 \times 10^{-3}$

$1.0 \times 10^{-3}$

$2.0 \times 10^{-4}$

2.2

1.5

150

4.1

2.8

1.2 (Equil.) 
- All of the steam generated in the boildown phase (containing all of the noble gases, $30 \%$ of the iodine and up to $5 \%$ of the ruthenium) is discharged to the cell atmosphere and exhausted through the cell ventilation system. (11)

- The ventilation systems incorporate particulate filtration that renoves $99.9 \%$ of all aerosols.

Approximately $90 \%$ of the fissions are assumed to occur during the initial burst generating up to $2 \times 10^{5} \mathrm{Ci}$ of radioiodine and noble gases during the initial few minutes. Cell ventilation flow can be reduced automatically which decreases the rate of release of the radionuclides and increases the duration in which natural removal processes (plate out, deposition, gravitational settling, etc.) can be operative. Assuming a higher rate of air exchange increases the rate but not necessarily the total quantity emitted. An exchange rate of five air changes per hour was arbitrarily selected and exponential dilution of the airborne concentration in the cell assumed. The assumed rate of release and total release as a function of time are shown in Figure 4 and indicate up to $10^{5} \mathrm{Ci}$ are emitted during the first $10 \mathrm{~min}$.

The significant radionuclides and the postulated release are shown in Table 2. The quantity reaching the atmosphere depends upon whether the ventilation system is assumed to remain intact or not. In order to maximize the release a breach in the ventilation system was assumed as a result of a nuclear excursion. The noble gases are the principal radionuclide emitted with $30 \%$ of the iodine generated and $0.1 \%$ of the ruthenium present in the irradiated fue 1 made airborne as "nuncondensible" vapor. The remaining $4.9 \%$ of the ruthenium is assumed to plate out or be removed by the particulate filters in the exhaust system.

\section{IV.2.2 Explosion in High Activity Waste (HAW) Concentrator}

If significant quantities of organic liquids used in the process are allowed to remain in contact with heated nitric acid and if the nitrated products ("red oil") allowed to accumulate, an explosion may occur. The blast 


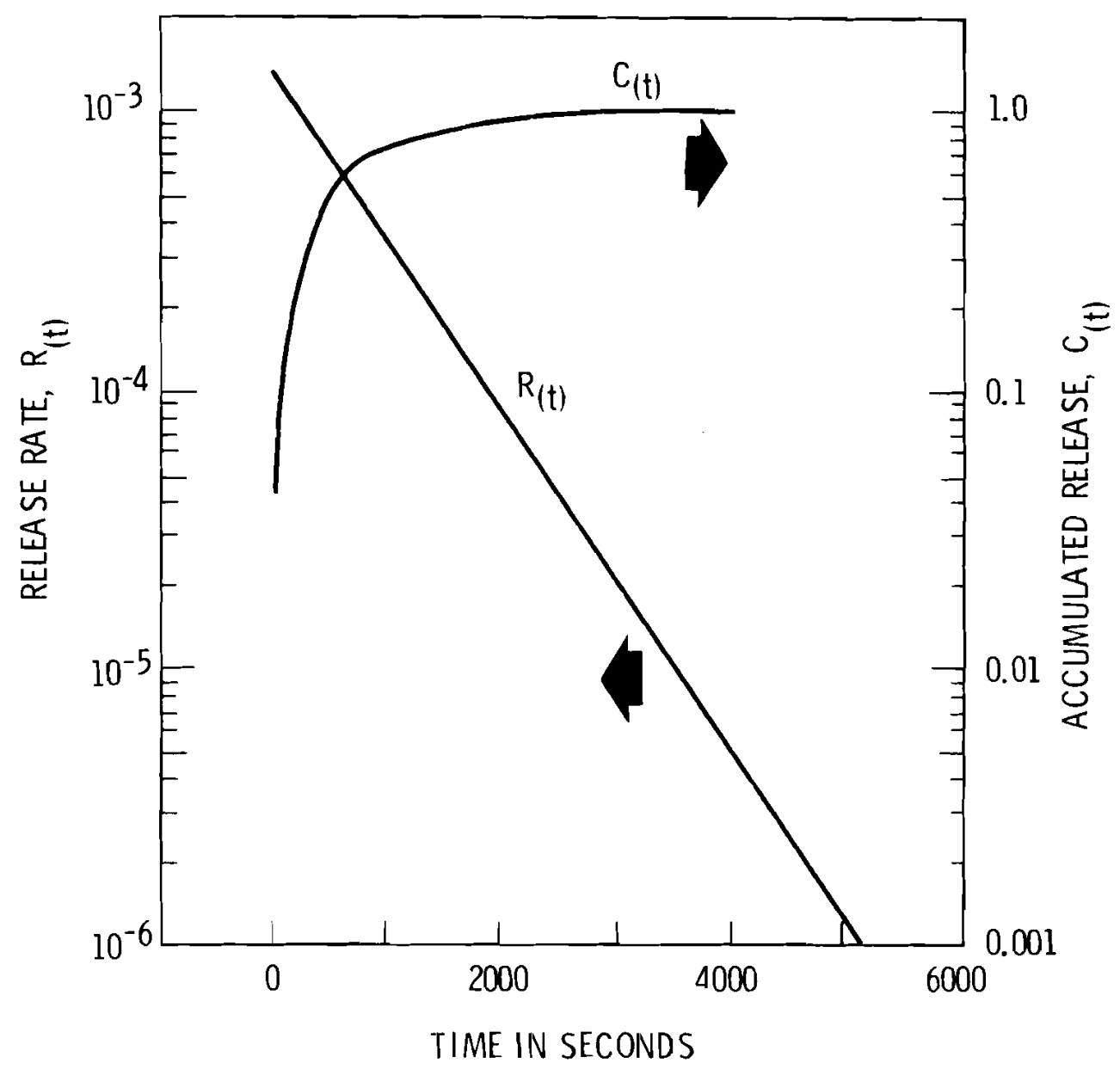

FIGURE 4. Release Rate, $R(t)$, and Accumulated Release, $C(t)$, Assuming Five Cell Air Changes Per Hour, Normalized to an Initial Concentration in the Cell of Unity 

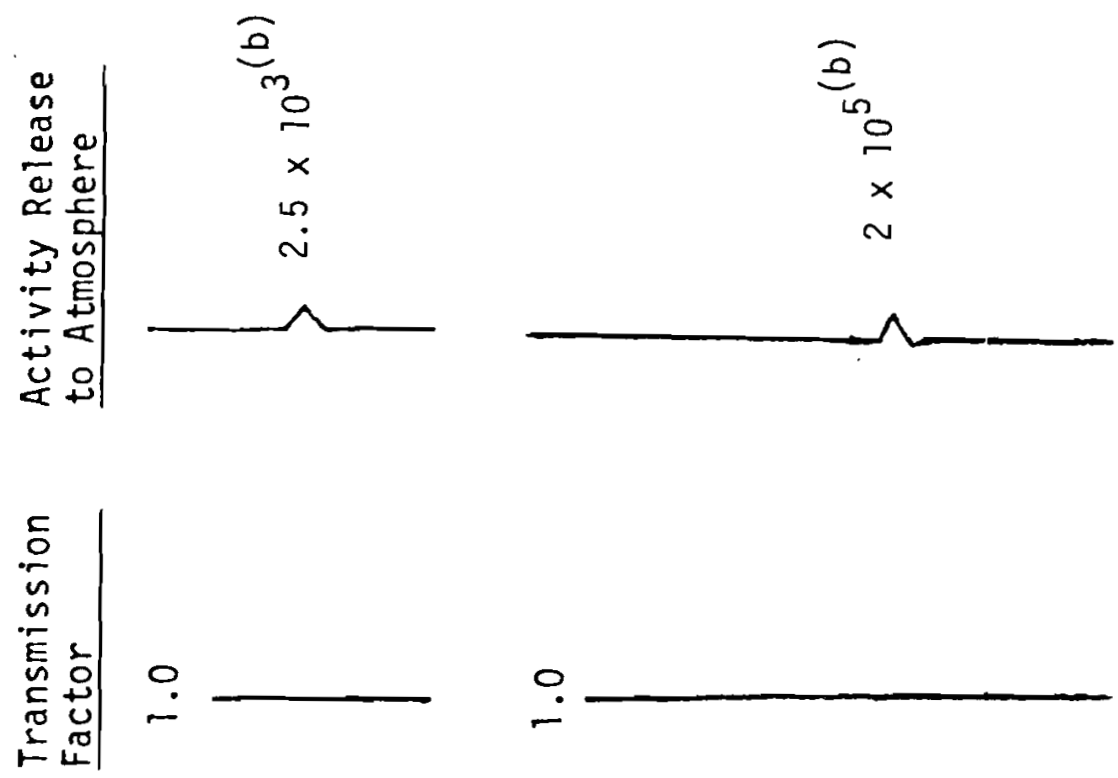

용
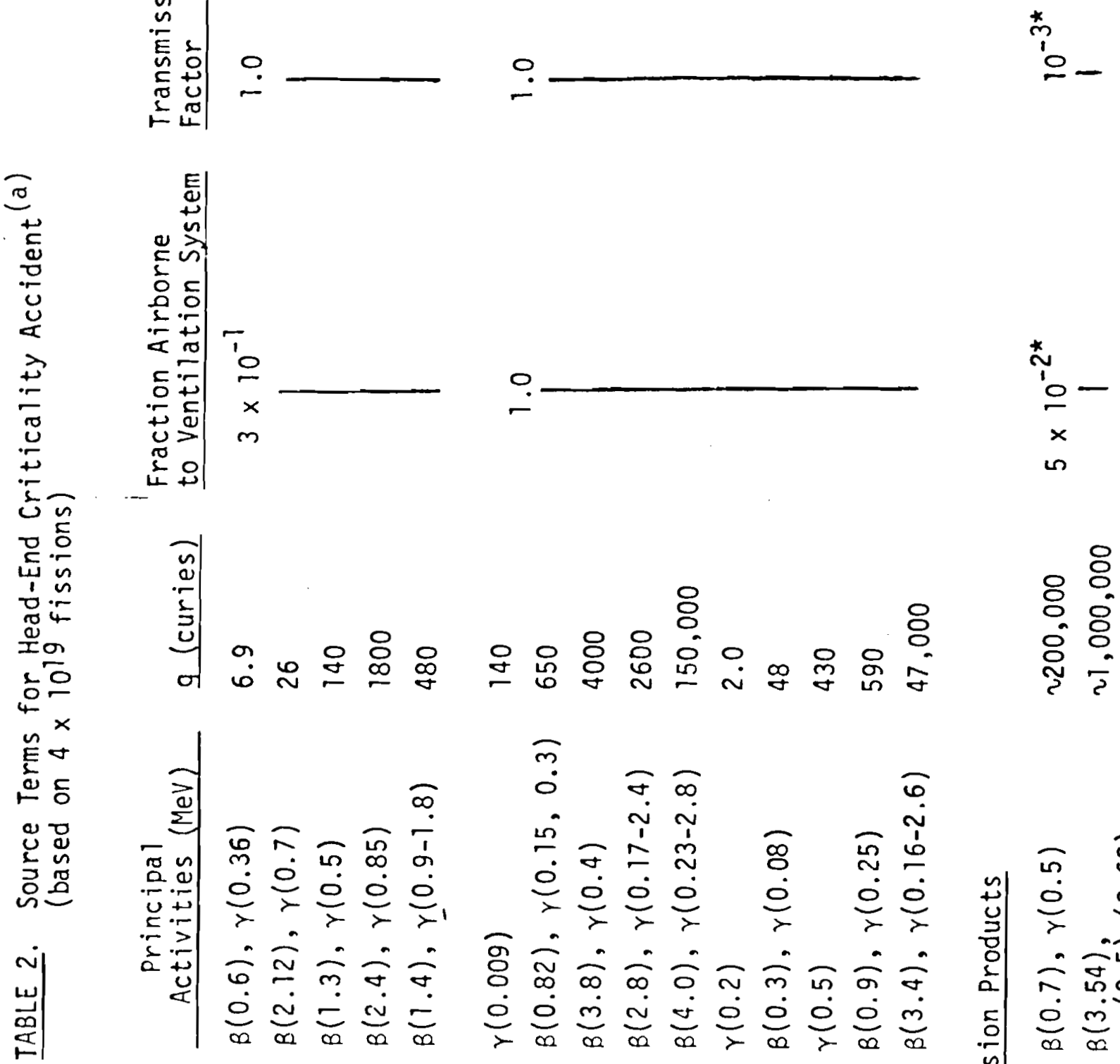

25

政

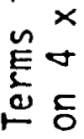

产

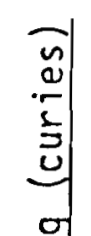

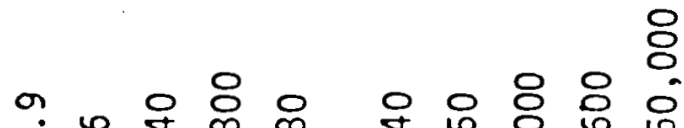

:

$\begin{array}{ll} & 8 \\ 8 & 8 \\ 8 & 8 \\ 8 & 8 \\ \text { 을 } & 0\end{array}$

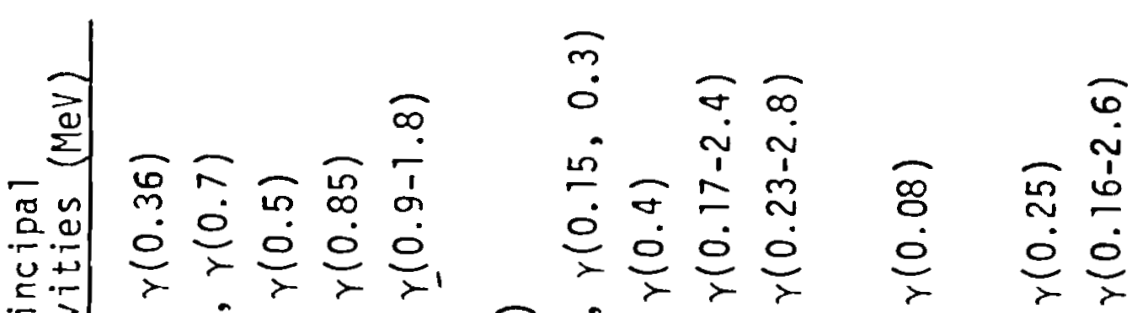

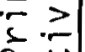

$-\dot{0} \cdot \dot{0}$

के

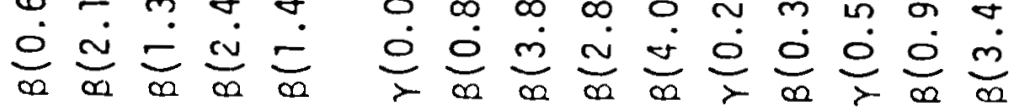

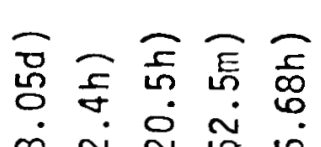

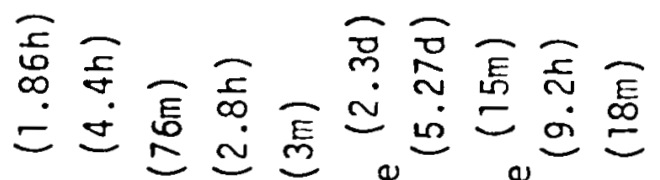

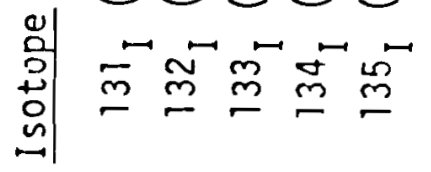

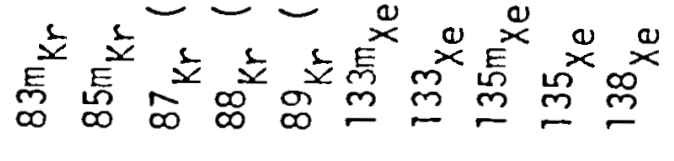

in

ก)

तु

م

$\geqslant \bar{c}$

$\because \frac{0}{0}$

ริㅇㅇ

艺

$\stackrel{\sim}{2} \frac{\pi}{0}$

กิ

웅 $\frac{m}{\infty}$

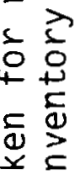

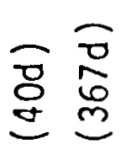

뭉ㅁㅇ

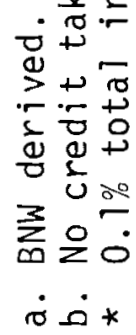


effects of such an explosion was estimated to be equivalent of 3 ib of TNT with a shock wave of $800 \mathrm{psi}$ and an energy of $230 \mathrm{ft}-1 \mathrm{~b} / \mathrm{ft}^{2}$ at a distance of $15 \mathrm{ft}$.

For the purposes of this study, the following assumptions are made.

- The concentrator ruptures and the entire contents of the concentrator is displaced.

- A liquid aerosol with a mass concentration equivalent to rain $(100 \mathrm{mg} / \mathrm{cu} \mathrm{m})$ or fog $(10 \mathrm{mg} / \mathrm{cu} \mathrm{m})$ remains suspended in the air after the blast.

- The cell volume is $2850 \mathrm{cum}$. Thus from 28.5 to $285 \mathrm{ml}$ of solution in the concentrator is airborne.

- Ventilation is approximately 5 air exchanges per hour. (Isolation of the cell volume is not postulated to maximize the release of radioactivity.)

A list of the principal radionuclides assumed to be in the concentrator at the time of the explosion and their estimated activity level are listed in Table 3. The volume of liquid in the concentrator is assumed to be 230 gal. Thus $3.3 \times 10^{-4}$ to $10^{-3}$ of the nonvolatile materials are assumed to be airborne. Ruthenium is a semivolatile element with a complex chemical behavior. Thus it is postulated that $0.1 \%$ of the ruthenium is vaporized in a noncondensible form that is not removed by filtration. If the efficiency of the final filter banks is assumed to be $99.9 \%$ for the remaining radionuclides in the liquid aerosol, $1800 \mathrm{Ci}$ of ruthenium and 2 to $17 \mathrm{Ci}$ of the remaining radionuclides could be emitted. Automatic isolation by reduction of cell air flow can reduce the rate of release of activity. To obtain more stringent criteria, an exchange rate of 5 cell volumes per hour was arbitrarily chosen. Under these conditions, the initial rate of emission of activity $0.25 \mathrm{Ci}$ ruthenium per second and from $2.4 \times 10^{-4}$ to $2.4 \times 10^{-3} \mathrm{Ci}$ of the remaining radionuclides in solution per second.

* Questions and answers to Allied Gulf Nuclear Services, Inc., Barnwell Nuclear Fuel Plant PSAR 

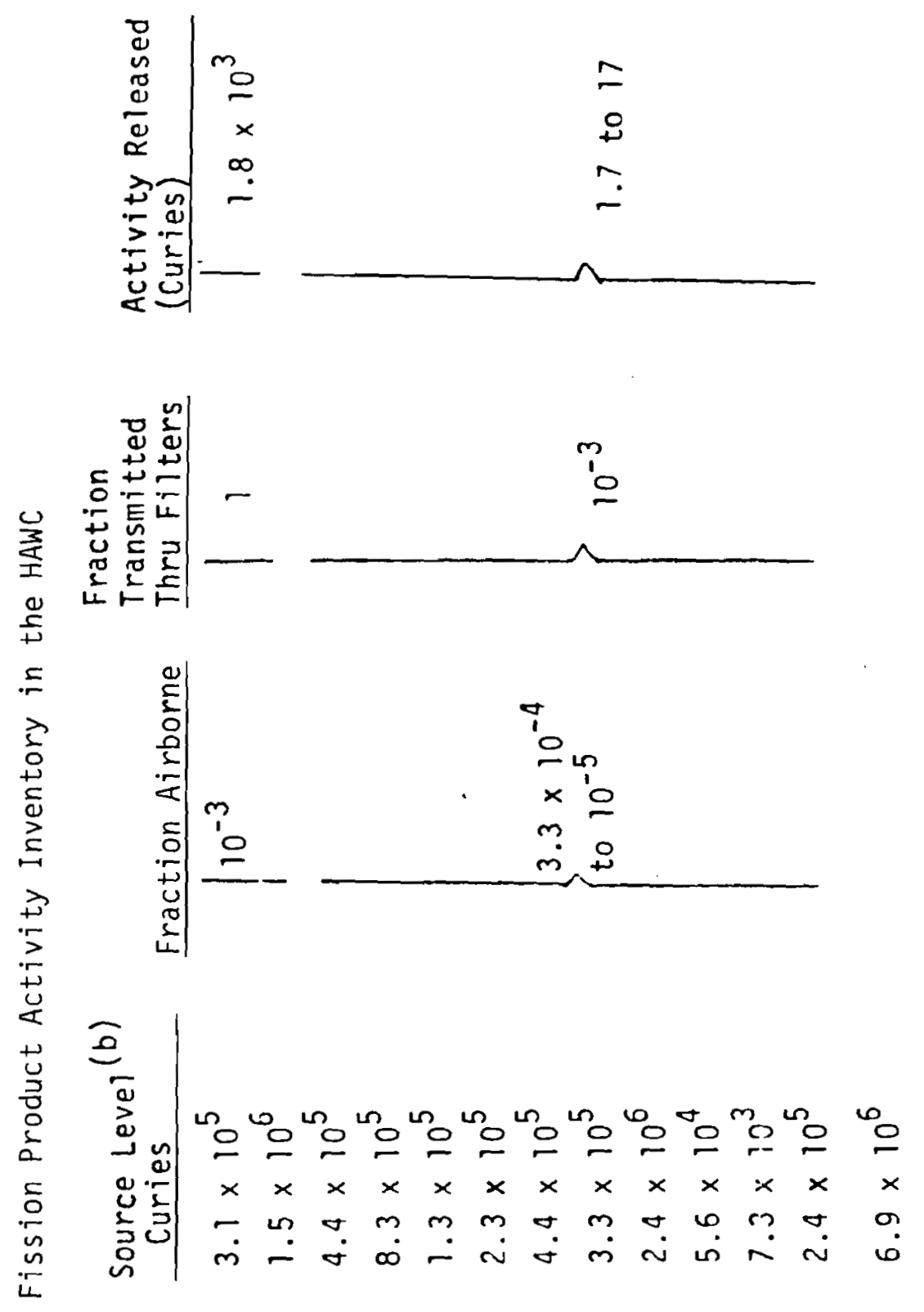

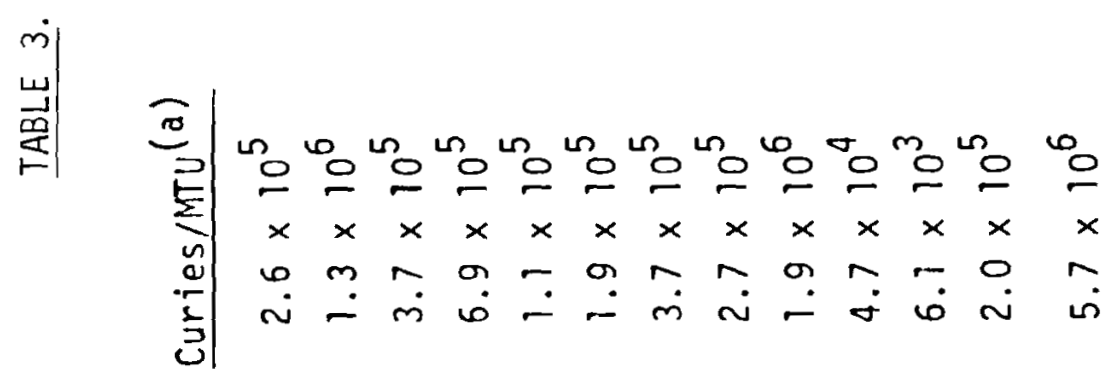

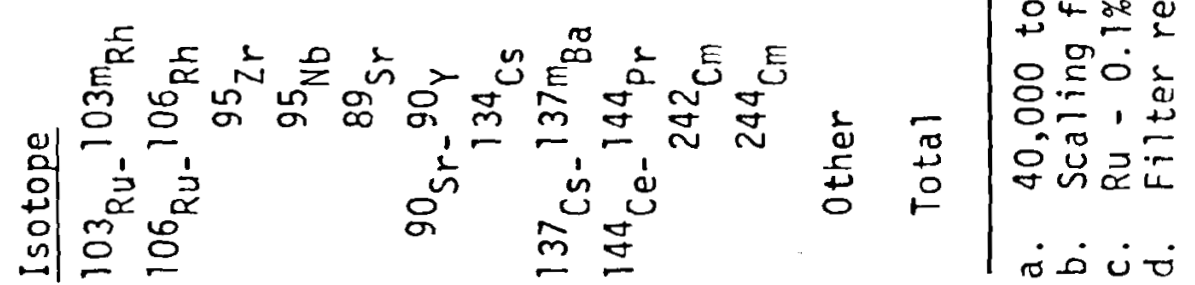




\section{IV.2.3 Fire Involving the Plutonium Product Solution System}

Extraction columns using organic extractant are used in this cell. The diluent is usually a kerosine fraction of aliphatic hydrocarbon that is combustible. If a significant quantity leaks from the piping or connections and ignited, a fire with sufficient magnitude and intensity to boil all the liquid from a solution in a vessel raised above the floor and cause loss of containment by heat warpage of metal may result. If such an event were to involve a vessel containing the largest plutonium inventory in the cell, as much as $10 \mathrm{~kg}$ of plutonium could be involved--under the isotopic distribution assumed for this study, a total of $1.4 \times 10^{5} \mathrm{Ci}$ of activity of which $97 \%$ is beta. (12) Experimental studies $(13)$ indicate that less than $0.5 \%$ of the plutonium was made airborne during the evaporation and calcining of plutonium nitrate solutions in low air flows. The duration of the fire is assumed to be 4 hours. Assuming a linear rate of release and a filter efficiency of $99.9 \%$, activity would be emitted at the rate of $5 \times 10^{-5} \mathrm{Ci} / \mathrm{sec}$ with a total release of $0.7 \mathrm{Ci}$.

\section{IV.2.4 Release of Radioiodine from the Dissolver Off-Gas System}

The presence of combustible organic liquids and the piping used to convey the liquid from one area to another poses the possibility of fires in many areas. If a fire were to involve the dissolver off-gas system the "worst case" appears to be the loss of all radioiodine in a caustic scrubber. Using similar assumptions and release factors discussed in the previous accident scenarios, the total activity and rate were less than those assumed for the Nuclear Excursion. (See IV.2.1.)

\section{IV.2.5 Fire in the Solvent Extraction cycle}

The presence of "solvent" in this area poses the possibility of a fire. Very little of the semi- and nonvolatile radionuclides were made airborne during the burning of purex type solvent. $(14,15)$ If noncondensible ruthenium present in the aqueous solution is evaporated, the release to the atmosphere increases. Even using "worst case" assumptions, the airborne release to the atmosphere from such an incident appears less than from a Nuclear Excursion (IV.2.1) or an explosion in the HAW concentrator (IV.2.2). 


\section{IV.2.6 Processing of Freshly Discharged Fuel}

The airborne release of radioiodine from the inadvertent shipment and reprocessing of recently discharged irradiated fuel was considered. Using the assumptions:

- A single fuel bundle is partially processed after 40 days cooling

- One ton containing $4 \times 10^{4}$ curies involved

- The iodine removal system is only $99 \%$ efficient

Under these postulated conditions, the release of radioiodine is less than that for the Nuclear Excursion.

\section{3 SUMMARY OF ACCIDENT SOURCE TERMS}

The total quantity of various radionuclides and their initial rates of release for the various events postulated in the preceding sections are listed in Table 4. The values shown are attempts to define an upper bound of possible activity release and hence, the range required of the emergency ins trumentation. 
TABLE 4. Potential Releases and Initial Rates of Release From Various Postulated Accident Scenarios

\section{Total Release}

(Ci)

2500

$2.0 \times 10^{5}$

1200

1800

1.7 to 17

\section{Release Rate ${ }^{(a)}$ \\ $(\mathrm{Ci} / \mathrm{sec})$}

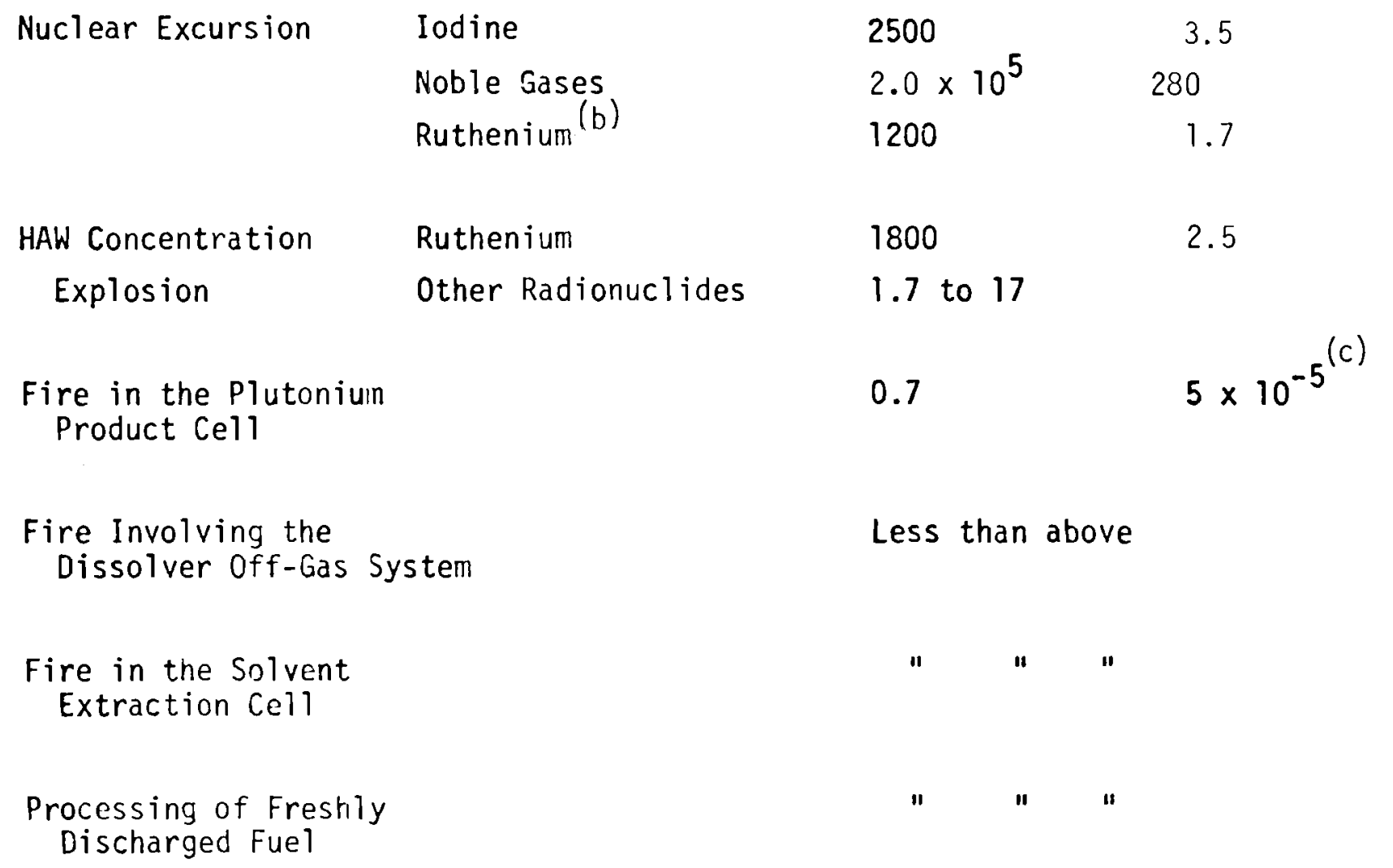

a. Based upon exponential emission of activity from cell volume at an air exchange rate of 5 cel1 volumes per hour -- $1.4 \times 10^{-3}$ fraction per sec.

b. "01d" ruthenium present in the fuel

c. Based upon linear release rate for 4 hours 


\section{EMERGENCY INSTRUMENTATION REQUIREMENTS}

Several types of emergency instruments or instrumentation systems should be utilized at the facility to characterize the severity and extent of the accident and to aid in the protection of operating personnel and inhabitants of the local environs. Instrumentation should be available to estimate the amount of radioactive material release to the environs via normal effluent channels. For radionuclides released via a final barrier break, estimates of the source term would be utilized with meteorological instrumentation measurements. These estimates and measurements should permit determination of the direction the cloud would follow and rapid calculation of the consequences within a 10 mile radius of the plant using a diffusion model appropriate to the site. In special cases a limited number of telemetered monitoring devices could be strategically located according to population and meteorological parameters of the site. These could permit qualitative confirmation of the cloud passage and source term. The need for an advisory prediction capability for longer times and correspondingly greater distances is the subject of a study, Atmospheric Release

Advisory Capability (ARAC), (16) being conducted by Lawrence Livermore Laboratory for ERDA. Survey instrumentation would be necessary to verify or refine early direct assessment of the environmental consequences in the same area and to aid in protection of operating personnel during efforts to stablize the emergency.

Based upon the postulated accidents and source terms developed in Section IV, the task of this study is to develop technical criteria for instrumentation systems to be used in the assessment of environmental conditions following plant emergencies.

For the purpose of estimating the upper range required of the monitoring instrumentation, the Barnwell main stack exhaust rate of $110,000 \mathrm{cfm}$ was assumed and the routine main stack effluent monitoring systems were considered to be those planned for the Barnwell plant.

In the proposed Barnwell effluent monitoring system the effluent sample is taken under near isokinetic conditions and treated by 
dehumdification and reheating before introduction to the monitoring system. The liquid from the dehumidifier passes through a gamma energy liquid monitor which can monitor five different gamma energy photopeaks with a six decade $\log$ readout $\left(10-10^{7} \mathrm{CPM}\right)$. The dehumidified effluent then is distributed to three monitoring systems. Two of these are moving filter paper particulate monitors that have gamma and alpha detectors respectively. The gamma system has five single channel analyzers to monitor different gamma energy photopeaks while the alpha system has two detectors to permit alpha detection immediately and after decay of natural or short half-life alpha emitters. The third system has a fixed filter silver zeolite I-131 gamma monitor and a $\mathrm{Kr}-85$ monitor chamber. All of the systems can be calibrated in terms of concentration per unit volume $(\mu \mathrm{Ci} / \mathrm{cc}$ ) except the iodine system which is a static system and measures accumulated activity. This system was cited as an example. Other acceptable systems are commercially available.

Detection and alarm instrumentation should be provided to protect plant personnel from criticality events. Specific instruments or instrument systems that are either required or recommended for coping with an emergency are described in subsequent subsections.

\section{V.1 CRITICALITY INSTRUMENTATION}

The primary purpose of the criticality alarm system is to initiate immediate evacuation of radiation workers in the event of accidental criticality. The device may detect gamma or neutron radiation, must be failsafe, respond rapidly, signal an alarm and establish the time of the event.

The stack release in the case of a criticality accident may involve some or all of the activation and fission products including noble gases, halogens and particulates. If the criticality occurs in a vessel that has a large inventory of "aged" fission products, the release of substantial amounts of ruthenium may occur depending upon the oxidizing conditions present. The volatile ruthenium fraction would not be contained by the final filters. 


\section{V.2 STACK EFFLUENT MONITOR}

Radioactive material may be released to the environs through the fuel reprocessing building ventilation system as a result of an accident. Such a release could occur whether or not the final containment barrier had been breached. The realistic cases indicated discharge primarily through the stack for both criticality accidents and process materials release cases. In nearly every case the effluent release point would be a stack approximately $100 \mathrm{~m}$ tall, resulting in considerable dilution and dispersal before the materials reached ground level. In passage through the ventilation system, the effluent would be subject to several sets of absolute filters, but in a serious accident one set of absolute filters might fail. Since the release of small amounts of fission products is expected to occur during normal operation of reprocessing plants, monitoring equipment would be in place to continuously monitor these effluents.

\section{V.3 AMBIENT RADIATION MEASUREMENTS}

In most post accident monitoring situations, portable hand-carried radiation survey meters will serve as the primary means of establishing the ambient radiation field at designated locations. However, appropriately placed remote area monitors could provide valuable information about the radiation fields in or near the fuel reprocessing facility which might otherwise be unobtainable because of high radiation levels and concommitant personnel hazards.

Fuel reprocessing facilities like Barnwel1 ${ }^{(6)}$ provide an area gamma monitoring system to measure radiation levels continuously at selected locations in the process complex. The location of the instruments satisfy the requirements for in-facility emergency ambient radiation measurement purposes.

The use of remote area monitors for measuring ambient radiation fields in the environs also could be worthwhile. The ambient radiation field is produced by mixed fission products from fallout on to the ground or other horizontal surfaces. A distinct feature of the ambient radiation 
field is its uneverness, in part caused by terrain factors, vegetation and shielding from structures, as well as micrometeorological conditions.

Although virtually any detector with a flat photon response can be used, an unpressurized air ionization chamber would probably be the most satisfactory. Ion chambers are fairly simple, inherently stable and rugged, have broad range, have minimal electronics and other supporting requirements and can be made to have flat energy response with relative ease.

Emergency monitoring equipment for accidental releases should be designed to compliment the routine monitoring equipment.

\section{V.4 DETERMINATION OF THE MAGNITUDE AND TRAJECTORY OF THE PLUME}

The decision making process following an accident in which a potentially hazardous release to the atmosphere has occurred at a fuel reprocessing plant requires information on the nature, extent and magnitude of the release, the trajectory, downwind air concentrations, ground deposition, and external dose rates. Data should be either directly obtained or calculated from measurements. To effectively implement emergency plans these data or estimates should be available as soon as possible after an accident.

Radiological measurements on a real-time basis in the immediate environs can be done for fission product releases. Since the number of monitoring stations required around a facility is so great and the location so variable (depending upon meteorological conditions and building wake effects), it is more worthwile to instrument a limited number of stations based upon the most prevailing winds and local population groups to verify source terms and plume trajectory.

The plume source term would have to be and could be estimated based upon the accident source term and with the actual meteorological data used to provide an estimate for appropriate actions. Building wake factors noting several references are given for reactors in Regulatory Guides 1.3 and 1.4 based on a volumetric building wake correction in the $0-8$ hour diffusion calculation for accidental releases. These factors can be 
expected to be applicable to fuel reprocessing facilities, since they are based on general relationships which do not apply just to reactor buildings.

Estimation of ground level air concentrations downwind require information on the release height and the relative buoyancy of the plume. The level of rise of the plume centerline as a function of downwind distance can be estimated if the total sensible heat input into the release and the vertical atmospheric stabilities are known. (17) Visual observations can be used as a measure of the plume rise in cases where the plume is visible.

In the event of an accident resulting in a leak of radioactive materials to the atmosphere, real-time onsite meteorological data must be used to provide a realistic estimate of the actual path of travel of the plume and the concentrations in the plume as a function of space and time. This requirement exists on two time scales. The first requirement is to immediately assess the area to be affected by the accident and to determine and implement the actions appropriate to minimize the direct inhalation hazard to individuals within and beyond the plant boundary. The second requirement is to conduct a detailed post-accident analysis to determine the effects of the accident and the action required to protect individuals from resuspension of deposited materials.

Real-time and post-accident analyses require quick response to a real and singular event, in comparison with the preoperational accident analyses which are based upon climatological data and result in probablistic statements of effect. This difference places constraints upon instruments, data handling procedures, analytical techniques and modeling requirements not common to preoperational evaluations. The meteorological criteria recommended in this report are intended to reflect this basic difference, taking into account the state-of-the-art in meteorological instrumentation and diffusion modeling.

Since specification of criteria for meteorological systems that would be optimum for al1 sites and accident situations is not possible, the criteria described are considered minimal requirements. For example, the required number and spacing of wind stations outside of the plant boundary will vary because of topographic variability and complexity of local 
meteorology. These considerations require the evaluation of meteorological emergency preparedness instrumentation systems on a site-by-site basis. The purpose of such an evaluation should be to determine the compatibility and adequacy of the meteorological system for the implementation of the real-time emergency plan and for conducting an appropriate post-accident analysis at that site.

Data requirements may also vary with the model(s) selected for estimating diffusion. The accuracy requirements identified for specific types of measurements are those considered appropriate to the models employing that type of measurement. The specification of a particular model(s) with subsequent data handling and analysis procedures, has not been included within the scope of the present study.

\section{V.5 RADIOLOGICAL MEASUREMENTS IN THE ENVIRONS}

Arrangements may exist for radiological monitoring in the environs around nuclear facilities, including those systems now coordinated by the Environmental Protection Agency. (18) In general, these stations are not oriented to detection, quantification, and prediction in the early postaccident hours and are not likely to be appropriately located to be useful for prompt response planning. The location of local air pollution sampling stations should also be known. These can possibly be utilized to determine cloud passage and deposition by use of portable monitoring instruments and laboratory evaluation. Civil Defense and other governmental emergency teams are also unlikely to be able to provide prompt determination of the extent of the impact on the environs. The availability of such assistance or control if required should be detailed in emergency plans for the facility.

Most emergency monitoring in the environs is accomplished with portable (or mobile) instruments, for it would be forbiddingly expensive to instrument and continuously monitor large areas of the environs. However, a few critical locations can be usefully monitored on a more or less continuous basis, using fixed $A C$-powered instrumentation. 
Passive dosimeters such as environmental TLD'S are located around many nuclear facilities to measure the facilities addition to the natural radiation background. These will provide a measure of the dose in the environ under emergency conditions if collected and a readout device is readily available.

The effectiveness of routine offsite sampling stations in providing useful information in the event of an accidental release should not be overlooked. Portable survey instruments may be used to measure the deposition on particulate air filters at continuous air sample locations and provide a rapid indication of fission product cloud passage. In addition, analysis of air filters and charcoal canisters provide a second order of field data generally obtainable within a few hours following the release (even though return to a laboratory may be necessary for data extraction).

\section{V.6 PORTABLE INSTRUMENTATION}

Following an accident, heavy reliance would be placed on portable instruments to obtain information regarding ambient radiation or surface contamination levels both at or near the accident site and in the environs. The information obtained with these instruments may be used as the basis for actions involving rescue or evacuation of personnel or the protection of health and property. In addition, these instruments may be useful in mapping radiation fields, assisting in contamination control, and even as the means of identifying personnel exposed to fast neutrons from a criticality. 


\section{PERFORMANCE CRITERIA FOR EMERGENCY INSTRUMENTATION}

The discussions in this section are divided according to the type of instrumentation being considered, i.e., criticality detection and alarm, radiological instrumentation, both fixed and transportable, and meteorological instrumentation. A general discussion of design consideration, followed by a set of more specific performance criteria, is presented for each type of instrumentation. Throughout these criteria four verbs are used to indicate the degree of rigor intended by the specific criterion. "Shall" and "Will" indicate that strict application of the criterion is possible and is considered necessary to assure that the instrumentation or systems wil1 perform as needed during an emergency. "Should" or "Would" indicates that the application of the criterion is desirable, even if unattainable with current instrumentation.

Some of the radiological and environmental criteria are severe, and calibration or certification are beyond the capability of individual nuclear facilities. Therefore, these instruments, systems or individual components should be thoroughly tested at least once under all extreme conditions of operation to assure conformance with the criteria.

\section{VI.1 CRITICALITY DETECTION AND ALARM SYSTEM}

Criticality instrumentation is probably the most important emergency instrumentation from the workers radiological safety standpoint. Criticality detection and alarm system requirements have been presented in numerous reports and standards. $(20,21,22)$ Personal dosimetry systems for individual radiation workers such as TLD badges and neutron badges are not considered here. The normal passive criticality neutron threshold area detectors are assumed to be in place as required by regulations and licenses.

The primary purpose of the criticality alarm system is to initiate immediate evacuation of people in the event of accidental criticality. The system should be designed to 1 ) detect a criticality event by the attendant high radiation, 2) signal evacuation, 3) summon help, and 4) establish the time of event for analysis. The system could ${ }^{(23)}$ also be adapted to 
provide a recording of the neutron dose rate after the event has been signalled. This would require remote switching to the dose rate mode. For the purpose of this study such a capability is not suggested as necessary.

In order to reduce the frequency of false alarms, the criticality detectors should be operated such that two or more detectors must be tripped in order to sound the alarm. This will require that two or more detectors be located sufficiently close to each quantity of fissile material to respond to the minimum foreseeable burst with consideration of the trip point and intervening shielding.

A minimum of two detectors $(n \geq 2)$ is sufficient if a detector upon failure goes to the alarm mode; a minimum of three detectors $(n \geq 3)$ is required if on failure a detector does not go to the alarm mode. The detectors should activate a unique alarm as described in ANSI N2. $3^{(24)}$ when two out of $n$ detectors are activated. Wiring for such a system should be isolated and protected from building operations interference.

One satisfactory criticality detection system involves an undermoderated $\mathrm{BF}_{3}$ tube with an internal alpha source to provide simulated neutron background pulses for the audit circuits. (25) The appendix to ANSI N16.2-1969 shows a system based upon gamma dose rate but the response time, reliability and the fact that it is a secondary measurement suggest the neutron dose equivalent rate measurement should be preferred.

The system should be provided with emergency power, and the loss and restoration of power to the system should not result in a criticality alarm signal. If the system is operated from normal electrical supplies, the power interruption should not cause an alarm while emergency power is being switched into the system.

VI.1.1 Criticality Detection and Alarm System Performance Criteria

- The detection system shall be designed primarily to act as an alarm trigger. 
- If detectors serve as a post-alarm dose-rate monitoring system, remote switching shall be used to switch to the other mode after the alarm.

- The system response time (i.e., the interval between the detection threshold and the time the alarm sounds) shall be less than $500 \mathrm{~ms}$.

- A minimum of two out of $n$ detectors in alarm mode shall be required to sound the alarm signal.

- If the detectors fail to the alarm mode, then at least two detectors ( $n \geq 2$ ) shall be located so as to respond to a minimum burst. If the detectors do not fail to the alarm mode, then at least three detectors $(n \geq 3)$ shall be located so as to respond to a minimum burst.

- An annunciator shall signal both visually and audibly any failure or alarm condition of any detector in the building.

- An annunciator which will signal power loss to the criticality alarm system shall be installed in the facility at a location which is normally occupied during normal building use.

- A central panel which contains a readout of all alarm system conditions should be provided.

- The criticality alarm system in the facility shall be connected to emergency power.

- The wiring for the criticality detection and alarm system shall be insensitive to power transients in the facility including the loss of and reestablishment of power.

- The wiring for the system should be placed in conduits which are used only for the system.

- The system shall be designed for the alarm to sound continuously until reset. Consideration should be given to remote reset to facilitate reentry into the facility. 
BNWL-1857

\section{VI.1.2 Instrumentation Performance Criteria}

- Neutron detection with low gamma sensitivity should be considered. (50 R per hour gamma ray field should not cause an alarm trip.)

- The detector system design should be based on neutron integrated dose detection (i.e., should function as a neutron operated alarm trigger) coupled with low dose-rate rejection.

- The criticality detection system should be designed to be operated by excursions of any foreseeable size whether or not those excursions are themselves directly attended by unacceptable hazard to man.

- The detection threshold should be the minimum foreseeable spike yield over any duration within the range of foreseeable durations of delivery of that yield. The minimum foreseeable spike yield should be set at $10^{15}$ fissions unless the process involves considerable quantities of solid plutonium metals, when it should be set at $10^{14}$ fissions. For foreseeable durations, a range of $1 \mathrm{~ms}$ to $3 \mathrm{~s}$ should be considered.

- The largest foreseeable yield should be $10^{19}$ fissions, except where fissile solutions are processed and the presence of 100 gallon capacities (whether or not intended to receive fissile solution) cannot be considered to be improbabie, in which case the yield should be increased to a maximum of $4 \times 10^{19}$ fissions.

- Detectors should not be located in the immediate area of magnetic fields of high flux density.

- The criticality alarm signal shall be unique and shall not be used for any purposes other than to signal immediate evacuation in the event of accidental criticality.

- The criticality alarm signal shall be a complex sould wave with a fundamental frequency between 450-500 hertz, and with a modulating frequency of 4 to 5 hertz as specified in ANSI N2.3.

- The alarm signal shall be audible within a maximum of one-half second after activation of the radiation detector. 
- After initiation, the alarm signal shall continue to sound even though the radiation level falls below the alarm point.

- Sufficient alarm howlers shall be installed to achieve a sound level of at least $10 \mathrm{dBa}$ above the maximum background noise and not less than $75 \mathrm{dBa}$ in all locations in the facility which may be occupied (except for areas with very high background noise levels). The alarm shal1 not subject any personne 1 to sound intersities greater than $130 \mathrm{dBa}$.

- Areas with very high background noise levels may require that the audible signal be supplemented with visual signals, such as beacons. Instructions shall be posted at the entrance to these areas defining the meaning of the beacon.

\section{VI.2 RADIOLOGICAL INSTRUMENTATION}

Radiological instrumentation intended for use during emergencies must necessarily be completely reliable and be capable of operation under a variety of severe ambient conditions. To achieve this level of reliability, electronic components should reflect the latest thechnology, making maximum use of solid state devices, and in particular, integrated circuits. Instruments and instrument systems should be designed, both electronically and mechanically, toward maximum ease of maintenance, calibration, and operation. Readouts must be clear and easily read and interpreted under adverse lighting conditions.

Instrument resolution (readout capability) is here defined as the minimum detectable change in instrument response. This change in response shall be sufficient to cause a minimum deflection of $4 \%$ of full scale for 1 inear readouts and $8 \%$ of meter reading for logarithmic scale instruments. Logarithmic display instruments shall be limited to 2 decades per $90^{\circ}$ of meter movement.

Appropriate human engineering considerations are vital. Basic safety features, mechanical as well as electrical, must be incorporated into each instrument or instrument system. Test points and switches should be 
appropriately marked, and the requisite waveforms, voltages, or other parameters should be called out at the test point as well as in service manuals.

Overall system accuracy should be within $\pm 40 \%$, with a precision (reproducibility) of $\pm 10 \%$ for any single level.

The instrument or instrument system should be unaffected by external radiofrequency, microwave, magnetic or electrostatic fields.

Although some systems external to the facility should be enclosed in relatively weatherproof, temperature controlled buildings, all instrumentation nonetheless needs to be capable of operation under varied environmental conditions in the event of power failure, earthquake, etc. Thus, the operating temperature range of the equipment should encompass the extremes anticipated. Where the instrumentation may be exposed to ambient outside temperatures, the 50 year extremes should be applied. Temperature compensation for the detector or other sensitive components may be required.

Instrumentation shall be capable of normal operation, over the anticipated temperature range, in relative humidities of up to $95 \%$.

Systems need to be sufficiently hardy so that no lasting detrimental effects will result from the most severe seismic disturbance expected to be encountered. Sound pressures as high as $100 \mathrm{dBa}$ in the frequency range of 1 to $1000 \mathrm{~Hz}$ shal1 cause no detectable change in instrument readings.

\section{VI.2.1 Installed Radiological Instrumentation}

Much of the total emergency radiation monitoring instrumentation package will consist of installed or fixed instrumentation at a specific location. Considerable functional equivalence of instrument modules will permit design and use of many interchangeable units. Where possible, functional entities, e.g., power supplies, circuit modules, units and components should be interchangeable, thereby providing demonstrable practical advantages, including:

- sma71 parts inventory requirements 
- rapid in situ repair capability by module replacement, permitting functional capability to be maintained.

- reduced training requirements, since maintenance personnel need be familiar with fewer basic parts

- minimization of design and installation cost.

The overall system should be capable of operating both on 117 volt, $60 \mathrm{~Hz} \mathrm{AC}$ line and secondary or emergency power sources. The latter can either be a secondary AC generator designed to come on in the event of a power failure, or a DC system using batteries maintained by a trickle charge.

Insofar as is practicable, criteria stated in this subsection refer to the overall system including the detector, rather than a specific component or unit. The criteria are not intended for portable radiation instruments or meteorological instrumentation. Generalization will allow for some choice of modules, units and components, and minimize "locking in" on specific designs. The entire system should be unaffected by power surges, external $r f$ or magnetic fields, and AC induced fields and transients. To best achieve this independence, a separate instrument power circuit is recommended. Isolation transformers, while effective in many instances, can be adversely affected or even rendered inoperative by extraordinary demands of a major accident.

The instrument system inclusive of the detector should not paralyze, i.e., indicate downscale, in radiation fields greater than the intended range. Readout should be accomplished without recourse to manual range changing, since in the emergency situation, adjustment of the instrument system may be impractical. Automatic range changing with linear readout, logarithmic readout, or digital readout are acceptable methods of presentation. Remote readout is recommended in a central process control station that is designed as the emergency control center. This process control center should be located so that access is possible during postulated 
emergencies. In addition, a readout should also be provided at the detector location. This readout is of value for field calibration and could in many instances be of value in the emergency situation as well.

\section{VI.2.1.1 Systems Performance Criteria}

Except as noted, the electronics shall meet the specifications for and be compatible with the AEC standard nuclear instrument modules, (26) thus ensuring a basic standard and providing ease of maintenance through interchangeability and compatibility.

- All modules shall be accessible for test without removal from the circuit. Plug-in type units should be used if available, other considerations being equal.

- Switches and other controls shall be protected to prevent inadvertent deactivation or operation of system.

- The system shall have an internal electronic calibration check which shall check operation of all circuitry other than the detector.

- The system shall be fail-safe; in the event of a malfunction or failure, an internal audit circuit shall be activated and transmit an appropriate signal to a central manned location.

- The system should be capable of operation on $117 \mathrm{~V} 60 \mathrm{~Hz} A C$ and should be unaffected by voltage or frequency changes of $+20 \%$. Emergency power capability should be included in the design and installation and should be automatically implemented when required, with no delay which would cause a malfunction in the system.

- The entire system should be unaffected by power surges, external rf or magnetic fields, and AC induced fields and transients. To best achieve this independence, a separate instrument power circuit is recommended. Isolation transformers, while effective in many instances, can be adversely affected or even rendered inoperative by extraordinary demands of a major accident.

- There shall be no deleterious effect to the system from radiofrequency field intensity of $1000 \mathrm{~V} / \mathrm{m}$, microwave exposure to $10 \mathrm{~mW} / \mathrm{cm}^{2}$, 
photon exposure to $5 \times 10^{5} \mathrm{R}$ referenced to the energy range between 0.6 to $1.25 \mathrm{MeV}$, and external electrostatic fields of $5 \mathrm{~V} / \mathrm{cm}$.

- The operating temperature and relative humidity ranges of the system shall encompass the extremes anticipated. Where the instrumentation may be exposed directly to ambient outside temperatures, the $50 \mathrm{yr}$ extremes shall be applied.

- The instrument system, when tested, shall be unaffected by relative humidities from $40 \%$ to $95 \%$ over the temperature range of $60^{\circ} \mathrm{F}$ to $120^{\circ} \mathrm{F}$ and shall be splashproof.

- The instrument system shall be able to withstand mechanical stress equivalent to a peak overpressure of $5 \mathrm{psi}$.

\section{VI.2.1.2 Performance Criteria for Air Concentration Leve1 Instrumentation}

In addition to the general criteria in VI.2.1.1, the following criteria sha11 apply:

- Detection of particulate radioactivity should be on the basis of betagamma counting.

- For particulate radioactivity, the minimum detection range shall be $10^{-5} \mu \mathrm{Ci} / \mathrm{cc}$ to $10^{1} \mu \mathrm{Ci} / \mathrm{cm}^{3}$, referenced to ${ }^{137} \mathrm{Cs}$, for work and process areas.

- For particulate radioactivity, the minimum detection range shall be $10^{-6}$ to $10^{0} \mu \mathrm{Ci} / \mathrm{cc}$, referenced to ${ }^{137} \mathrm{cs}$, in the plant environs.

- Overall system accuracy shall be $\pm 40 \%$ over the entire operating range, with precision of $\pm 10 \%$ at the $95 \%$ confidence level for any single measurement level.

- Overall electronic system response (0 to $90 \%$ of full reading) time shall be $\leq 2$ seconds on all ranges.

- For the operating temperature range, the temperature coefficient shall be $\leq 0.5 \%$ per ${ }^{\circ} \mathrm{C}$ and it should be $\pm 15 \%$ over the entire range. 
- The instrument system shall be equipped with an alarm capable of being externally set to alarm at any point over the stated range.

- The alarm should be both audible and visible and should be capable of reset without removing the instrument from service.

- The alarm shall sound at the emergency control center and at the instrument for in-facility locations, whereas instrumentation located in the environs need only alarm at the emergency control center.

- Logarithmic or digital readout should be employed.

- Readout capability shall be provided at a central process control station designated as the emergency control center and at or near the instrument.

\section{VI.2.1.3 Performance Criteria for Ambient Radiation Instrumentation}

In addition to the general criteria in VI.2.1.1, the following criteria shall apply to ambient radiation instrumentation systems:

- Detection of ambient radiation should be on the basis of unpressurized air ionization chambers!

- The instrument system shall operate within the range of $10^{-3}$ to $10^{4} \mathrm{R} / \mathrm{hr}$ whether located within the facility or in the environs.

- Overall system accuracy sha11 be $\pm 40 \%$ over the entire operatina range, with precision of $\pm 10 \%$ at the $95 \%$ confidence level for any single measurement level.

- Overal1 system response ( 0 to $90 \%$ of ful1 reading) time, after a 1 minute warm-up, shall be $\leq 10$ seconds on the most sensitive ranges and $\leq 2$ seconds on the $10^{4} \mathrm{R} / \mathrm{hr}$ full scale range. Variable response time capability may be included. Response time to a decreasing fieid (full reading to $10 \%$ of original reading) shall be no greater than response times to increasing fields. 
- For the operating temperature range, the temperature coefficient shal1 be $\leq 0.5 \%$ per ${ }^{\circ} \mathrm{C}$ and it should be $\pm 15 \%$ over the entire range.

- The instrument system sha11 be equipped with an alarm capable of being externally set to alarm at any point over the stated range. The alarm should be both audible and visible and should be capable of reset without removing the instrument from service. The alarm shall sound at the emergency control center and at the instrument for in-facility locations, whereas instrumentation located in the environs need only alarm at the emergency control center.

- Logarithmic or digital readout should be employed.

- Readout capability shall be provided at a central process control station designated as the emergency control center at or near the instrument.

\section{VI.2.2 Transportable Radiation and Contamination Measurement Instrumentation}

Contamination and ambient radiation survey instrument measurements are intended to supplement those obtained from fixed instrument systems and to aid in the protection of operating personnel during efforts to stabilize the emergency. It is prohibitively expensive to have a fixed instrument system in the environs that will provide a complete coverage for all releases considering a 11 possible meteorological conditions. Characteristically, these instruments need to be highly flexible and yet rugged in order to function as desired and withstand the rough treatment they may receive.

In the case of plutonium releases, the measurements may be the primary method of determining the magnitude of a release when an unusual route of release is possible. Confirmation of plume direction and source term will also be possible with transportable instrumentation.

Monitoring on an emergency basis following a fuel reprocessing plant accident wi11 normal1y be for beta-gamma medium energy radiation from 
ambient air and surface contamination. Releases involving only alpha emitters may become more important as facilities to convert the plutonium product from the nitrate to the oxide are added to permit transportation of the plutonium to a fuel fabrication plant.

\section{VI.2.2.1 Transportable Instrumentation Systems Performance Requirements}

The breadth of application of portable survey meters may require unusual design demands or several instruments to accomplish the tasks at hand. Two basic design concepts are 1) an instrument designed and used for a specific purpose, or 2) a universal electronics package designed to accept a variety of detectors, and possibly, readouts. Each concept has merits and has been applied in the field. Unfortunately, each also has serious drawbacks. For example, the individual instrument approach may require a relatively large number of different instrument types and may prove expensive and impractical from a logistics point of view. The "universal" electronics package requires additional sophistication on the part of the user with respect to detector selection and interpretation of readout; in addition, some compromises in individual detector capability may have to be made to achieve a high degree of universality.

A more truly universal design may be considered: a single instrument which will provide the necessary broad range for ambient radiation, betaphoton discrimination, contamination monitoring capability, and, possibly, an integrate mode. Such an instrument is not beyond the current state-ofthe-art and with solid state circuitry would not be prohibitively heavy. Recent commercial trends have been to instruments having these capabilities.

In recognition of the fact that different sites and locations may have different needs, both single purpose and "universal" instruments are included in the following considerations. However, the selection of a multipurpose or "universal" type instrument is usually recommended, since the advantages would seem to far outweigh the disadvantages.

Instrument design and evaluation can be considered in the context of three broad areas: mechanical, electronic and radiological. $(27,28)$ 
- Mechanical requirements include the need to be designed for 1) hard usage, 2) withstanding shock and 3) being operable in anticipated weather extremes or other similar situations.

- Human engineering aspects include consideration of safety hazards, along with ease of handling, readout, and servicing. The shape, size and weight of the instrument are important and obvious factors in ease of handling. The general external appearance of an instrument including location of switches and their switching arrangements can alone affect its acceptance by monitoring personne1. Consideration should be given to use of portable instruments by personnel wearing gloves and other personal protective clothing, to use at night or in inclement weather, and to the ease of decontamination.

- For ease of servicing, batteries should be readily accessible without removal of other components or a large number of fasteners. Use of low cost, common batteries is highly desirable and is strongly recommended, particularly if field replacement is required. Flashlight batteries, because of their low cost and availability, are the best choices. Batteries should meet the specifications published by the National Bureau of Standards. (29) Instruments so designed also can be compatible with standard mercury or alkaline cells. A carbon zinc battery will not operate below $0^{\circ} \mathrm{C}$ for more than a few hours without freezing. If instruments are to be operated in locations where temperabelow $0^{\circ} \mathrm{C}$ can be expected, alkaline batteries should be used for continued operation. Circuit boards, accessible from both sides and with labeled components, can also provide significant reduction of maintenance costs. Circuit boards should be keyed to prevent inadvertent erroneous positioning in the socket.

- Electronic components should reflect the latest technology and provide the highest reliability reasonably achievable. To this end, solid state devices should be used wherever possible to minimize current drain and reduce weight. 
MOS field effect transistor circuit, while far superior to an electrometer tube circuit with regard to current drain and stability.

Electromagnetic radiation of many kinds can cause unusual effects and spurious response. The circuitry, rather than the detectors, is more commonly affected. In most cases, well designed circuits with good electrical shielding will not be affected by electromanetic fields.

- The radiological response of the instrument system is the primary consideration. Survey meters should be responsive to both beta and photon radiation and should provide a reasonably accurate measure of dose rate, particularly if the readings obtained will serve as the basis for rescue work.

For rate meters, and in particular those which may be used as the basis for rescue efforts, $\pm 40 \%$ accuracy is necessary along with an upper 1 imit of at least $10^{4} \mathrm{R} / \mathrm{hr}$.

The instrument systems for a l.pha and low energy photon measurement will probably utilize different detectors and may also utilize specialized electronic systems. Plutonium dispersal accidents, except for criticality accidents, generally create an alpha and low-energy photon dose problem that has inhalation or internal dose significance but is of minimal external dose concern. Field measurements will be directed primarily to the rapid determination of environmental deposition consequences. Rescue and recovery work in a facility will require excellent respiratory protection and contamination control while external dose measurements will be of less concern.

A review of current instrumentation has indicated that the most versatile and useful instrument and detector system currently available is based upon a thin window, large area sodium iodide detector for detection of low energy photon. The Fidler (30-33) system, developed at the Lawrence Livermore Laboratory and studied and tested extensively for the last ten years, can provide a measure of contamination levels in the environment quite rapidly. The system may not meet the weight and ruggedness criteria proposed for portable instruments but appears to be capable 
of detecting contamination levels of approximately $300 \mathrm{nCi}$ of plutonium per square meter. The main advantage of measurement of the low energy photons rather than the alpha radiation is that the detector may be held at some distance from the surface during rapid scanning and respond to the material deposited over several square meters.

Portable beta-gamma monitoring instruments, as described in the preceding section, may well serve satisfactorily as mobile instruments. Recording capability and a special mount for the probe should permit safe operation from a surface vehicle or a boat by a single individual while continuously recording pertinent data. The conditions or requirements described for portable instrumentation should also apply for instruments used in mobile monitoring. Each separate component of the mobile instrument system should weigh less than $22.5 \mathrm{~kg}$ (50 1b).

Instruments to be used in an airplane should be designed to operate properly at an altitude of 5,000 feet and 100 feet over the surrounding terrain. (34)

\section{VI.2.2.2 Performance Criteria for Transportable Dose Rate and Contamination Survey Instrument}

- The instrumentation shall be capable of detecting alpha, beta and photon radiation, and of separating the contribution from each. To accomplish this, a detector system which can be operated bare or which can be shielded with $1 \mathrm{gm} / \mathrm{cm}^{2}$ of polyethylene or similar low $Z$ plastic should be used.

- The detection ranges shall be as shown:

Photon Exposure Rate:

$0.1 \mathrm{mR} / \mathrm{hr}$ to $10^{4} \mathrm{R} / \mathrm{hr}$

Beta Dose Rate:

$0.1 \mathrm{mrad} / \mathrm{hr}$ to $10^{4} \mathrm{rad} / \mathrm{hr}$

Alpha Contamination:

$500 \mathrm{~d} / \mathrm{m} / 100 \mathrm{~cm}^{2}$ to $10^{7} \mathrm{~d} / \mathrm{m} / 100 \mathrm{~cm}^{2}$

In recognition of the difficulties in design and construction of a single detector and/or instrument with such a breadth or range, two detectors or instruments are permissible, assuming that all the other criteria specified in this section are met and that a one 
decade overlap is provided. Linear scales are preferred for ease of readout and reduction of error in calibration.

- Photon energy dependence shall be $\pm 15 \%$ over the range $7 \mathrm{keV}$ to 2.75 MeV (more than one detector permissible).

- Detection capability shall be provided for beta particles with energies greater than $100 \mathrm{keV}$. The beta energy dependence should be $\pm 30 \%$ over the range 0.2 to $2 \mathrm{MeV} \mathrm{E} \max$.

- Angular dependence for photon measurement shall be $\leq 15 \%$ in a $2 \pi$ steradian frontal direction, referenced to photons with energies in the region 0.6 to $1.25 \mathrm{MeV}$.

- Readout for photon and beta instrumentation shall be direct and in units of dose or exposure per hour. However, high range instruments intended exclusively for rescue work may be calibrated in units of $\mathrm{R} / \mathrm{min}$ or $\mathrm{rad} / \mathrm{min}$, and if so, the instrument and readout should be clearly and distinctively marked. The readout shall be such that multipliers (e.g., X10, X100) shall be included.

- Readout for alpha instrumentation sha11 be direct. The readout shall be such that multipliers (e.g., X10, X100) shall be included.

- Overall instrument accuracy shall be $\pm 20 \%$ over the entire operating range, with precision of $\pm 10 \%$ at the $95 \%$ confidence level for any single measurement level.

- Overal1 instrument response ( 0 to $90 \%$ of full reading) time, after a one minute warm-up, shall be $\leq 10$ seconds on the most sensitive ranges and $\leq 2$ seconds on full scale ranges of $100 \mathrm{mrad} / \mathrm{hr}, 100 \mathrm{mR} / \mathrm{hr}$ and $5000 \mathrm{~d} / \mathrm{m} / 100 \mathrm{~cm}^{2}$ and higher. Variable response time capability may be included. Response time to a decreasing field (full reading to $10 \%$ of original reading) shall be no greater than response times to increasing fields. 
- Stability shall be evidenced by the ability of the instrument to maintain accuracy and precision for at least 24 hours after initial warm-up.

- Resolution (readout capability) is defined as the minimum detectable change in meter response. Resolution shall be $\leq 4 \%$ of full scale for a linear scale or $\leq 8 \%$ of a reading for log scale with a maximum of two decades per $90^{\circ}$ of meter movement.

- Detectors and associated electronic circuitry, readout and display devices, and power supplies shall be wholly interchangeable between instruments of a given type. With the exception of the detector and display, solid state electronics should be used throughout.

- The readout shall be lighted to permit use in darkness; selfillumination should be considered.

- A $10 \mathrm{mV}$ or $1 \mathrm{~mA}$ recorder output shall be provided for instruments which are to be used with a recorder.

- The instrument should be designed to be powered by readily available cells or batteries such as AA, C or D cells or 9-volt batteries meeting specifications published by the U.S. National Bureau of Standards. Compatibility with alkaline, Ni-Cd, or mercury cells should be considered. Provision for operation from a standard automobile 12 volt system and 117 volt, $60 \mathrm{~Hz}, A C$, also should be considered.

- Minimum battery lifetime shall be 200 hours of continuous duty operation at an exposure level of $10 \%$ the maximum full scale reading, at temperatures above $0^{\circ} \mathrm{C}$. At temperatures below $0^{\circ} \mathrm{C}$, alkaline batteries shall be used and the minimum battery lifetime shall be 100 hours of continuous operation.

- The instrument shall be equipped with a battery check switch and indicator of battery condition. Low or dead battery indication shall be positive, i.e., the instrument shall read upscale, and zeroing shall be rendered impossible. 
- When responding to levels in excess of the maximum range, the readout shall remain full upscale.

- Overall instrument response shall not change by more than $\pm 10 \%$ from the previous calibration when batteries are changed.

- The total weight of the fully assembled survey meter, including batteries, should not exceed $3 \mathrm{~kg}$ (6.6 lbs).

- For the operating temperature range the temperature coefficient shall be $\leq 5 \%$ per ${ }^{\circ} \mathrm{C}$, and it should be $\pm 15 \%$ over the entire range.

- The operating temperature range of the system shall encompass the extremes anticipated. Where the instrumentation may be exposed directly to ambient outside temperatures, the 50 year extreme shall be applied.

- The instruments shall be splashproofed. The instrument system shall be unaffected by relative humidities from $40 \%$ to $95 \%$ over the temperature range of $60^{\circ} \mathrm{F}$ to $120^{\circ} \mathrm{F}$.

- Response to noise shall be undetectable at noise pressure $\leq 100 \mathrm{dBa}$ (referenced to $0.0002 \mu$ bar) in the frequency range of 1 to $1000 \mathrm{~Hz}$.

- Extracameral responses should be undetectable in photon field to $10 \mathrm{R} / \mathrm{hr}$, referenced to $1 \mathrm{MeV}$ energy, and to beta fields providing an air dose of $10 \mathrm{rad} / \mathrm{hr}$, referenced to $2 \mathrm{MeV} \mathrm{E} \max$.

- The system shall be unaffected by magnetic fields with intensity to 10 oersteds.

- The system shall be capable of withstanding harmonic g loadings applied in each of three mutually orthogonal axis in the frequency range of 1 to $33 \mathrm{~Hz}$ with no lasting detrimental effects. The magnitude of the g loading shall be the larger of $1 \mathrm{~g}$ or the maximum $\mathrm{g}$ forces anticipated in the individual project siting specifications.

- There shall be no deleterious effect to the system from radiofrequency field intensity of $1000 \mathrm{~V} / \mathrm{m}$, microwave exposure to $10 \mathrm{~mW} / \mathrm{cm}^{2}$, 
photon exposure to $5 \times 10^{5} \mathrm{R}$ referenced to the energy range between 0.8-1.2 MeV, and external electrostatic fields of $5 \mathrm{~V} / \mathrm{cm}$.

- Geotropism: The change in reading with spatial orientation shal1 be $\leq 5 \%$ of full scale reading.

If an integrating capability is provided the following shall apply:

- Portable radiological instruments with integrating capability should have integrating ranges as shown:
Photon Exposure:
0.1 to $10^{4} \mathrm{R}$
Beta Dose:
0.1 to $10^{4} \mathrm{rad}$

Integrating units shall be equipped with an audible alarm having a continuous or intermittent warbling tone with a frequency in the region of 2 to $7 \mathrm{kHz}$ and a sound level of $85 \mathrm{dbA}$ at a distance of $50 \mathrm{~cm}$ from the instrument.

- The alarm shall be presettable to any level by an external switch. External reset capability shall also be provided.

- An alarm test position or switch shall be provided.

If the survey instrument is to be combined with recorders or air samplers and operated while carried (semi-portable), the following shall apply:

- The instrument will be capable of and designed for convenient transportability by a single person. This criterion does not preclude the use of back packs, neck or shoulder straps, belts, or other means of attachment to the body.

- The weight of the total instrument, including power source, will not exceed $22.5 \mathrm{~kg}$ (50 $\mathrm{lbs}$ ).

If the survey instrument is to be operated while mounted in an airplane, motor vehicle or boat (mobile), the following shall apply:

- Any of the instrumentation that may be used in an airplane shall be designed to operate properly at an altitude of 5000 feet and 100 feet over the surrounding terrain. 
- Mobile instrumentation shall be designed to provide a readout using a strip chart recorder.

- Each separate portion of the mobile instrument system shall weigh less than $22.5 \mathrm{~kg}$ (50 1bs).

\section{VI.2.3 Airborne Particulate Monitoring}

An important element of preparation for an emergency is to establish in advance the instruments and procedures to be used: 1) to quickly assess the seriousness of the event from the moment an accident involving release is recognized, 2) to determine airborne levels which will permit decisions and action regarding people downwind and, 3) after the fact, to reconstruct the event for the record and further assess the consequences of the release. All these activities are directed at preventing and mitigating human exposure.

The accepted ventilation configuration of fuel reprocessing plants is to collect and exhaust ventilation air through a single tall stack. Several additional exhaust points are associated with auxillary facilities and do not exhaust ventilation air from the main reprocessing facility. Monitoring instrumentation required for normal or routine operations is located on important streams to the main exhaust system as well as on the main stack. Under normal conditions, scrubbers, absorbers, and high efficiency filters remove virtually all particles and most volatile fission products, with the noble gases being completely released. Failure of one or more of these clean-up systems during an accident may provide a release path to the environs.

In the early stages of an accidental release the immediate concern is airborne concentrations in the environs. Monitoring stations will provide some information when suitably located for fission product releases. In the case of plutonium only releases, means should be available to sample and measure plutonium near the ground at points to be designated from the real-time meteorology and the knowledge concerning the gross nature of the accident. This would include knowledge of integrity of the physical plant, 
whether fire criticality event or transuranium release had occurred or not, apparent integrity of air cleaning, etc.

Accidents involving destruction of structural integrity or release through walls, door, etc., are considered to be highly improbable and are difficult to adequately sample and measure.

\section{VI.2.3.1 Sampling of Aerosol}

Collection of a representative sample of an aerosol requires appropriate consideration of many factors influencing the behavior of particles in air. The paramount consideration in air sampling for emergency instrumentation is the ability to detect significant concentrations of airborne radioactive materials rapidly and reliably.

The principal errors in sampling airborne particles arise from the deviation of particles from flow-stream lines at the sample probe inlet, incomplete mixing of the effluent, and nonrepresentative sampling in the effluent stream. As particles of a given material in a flowing medium increase in size, their inertia increases. At any given velocity, particles possessing sufficient inertia will cross the stream lines and deviate from the bulk flow. Thus, an important consideration in designing an aerosol sampling system is minimizing airborne particles leaving stream lines. This is achieved by near-isokinetic sampling. The aerodynamic size range of the particles constituting the aerosol should be known or if the size range is unknown, as in most accident situations, respirable sizes are assumed to be present.

\section{VI.2.3.2 Measurement of Accident Stack Release}

Measurement of radioactive aerosols can be categorized as either direct or indirect. Direct monitoring involves the measurement of radiation "in situ" in the effluent without removal of a sample from the system or without intervening treatment of any kind. This is a rapid method that in general requires relatively simple instrumentation.

The direct measurement of accidental releases from fuel reprocessing facilities is of limited usefulness because of the mixture of noble gases, 
BNWL-1857

semivolatile andparticulate fission products that may be released. Direct measurement can provide qualitative results but are difficult to quantify under emergency conditions. Thus the use of the "in situ" technique is considered to be impractical for emergency purposes and is not recommended.

Indirect measurement of airborne radioactive materials requires collection, treatment of the accumulated materials, measurement of the radioactivity and the application of appropriate corrections as necessary. Collection of a representative sample of airborne material is not a trivial task. The point and method of sample collection must be chosen with careful attention to factors which may make the sample unrepresentative. The degree of freedom in choice of sampling location may be very restrictive or nominal depending on the nature and point of release, the effects of the mechanism causing the release, the physical and chemical characteristics of the airborne material, and the basic aerosol physics considerations for obtaining a representative sample.

The monitoring system for the accidental stack release could be challenged by concentrations that may be substantially greater than the capability or range of the system used for routine monitoring. The postulated normal release rates and concentrations from the Barnwell plant are compared to the postulated maximum accident release rates and concentrations in Table 5.

TABLE 5. Routine and Accident Stack Concentrations

\begin{tabular}{|c|c|c|c|c|c|}
\hline \multirow[b]{2}{*}{ Isotope } & \multicolumn{2}{|c|}{ Routine ${ }^{(a)}$} & \multicolumn{2}{|c|}{$\operatorname{Accident}^{(b)}$} & \multirow[b]{2}{*}{ Diff } \\
\hline & $\mu \mathrm{Ci} / \mathrm{sec}$ & $\mu \mathrm{Ci} / \mathrm{cc}$ & $i / \mathrm{sec}$ & $\mu \mathrm{Ci} / \mathrm{CC}$ & \\
\hline loble Ga & $4.3 \times 10^{5}$ & $8.3 \times 10^{-3}$ & $2.8 \times 10^{8}$ & $9.9 \times 10^{0}$ & $\overline{10^{3}}$ \\
\hline Iodine & $1.2 \times 10^{-2}$ & $2.3 \times 10^{-10}$ & $3.5 \times 10^{6}$ & $1.2 \times 10^{-1}$ & $10^{9}$ \\
\hline irticulate & $3.7 \times 10^{-1}$ & $6.7 \times 10^{-9}$ & $2.5 \times 10^{6}$ & $8.8 \times 10^{-2}$ & $10^{7}$ \\
\hline Plutonium & $4.3 \times 10^{-3}$ & $8.3 \times 10^{-11}$ & $5 \times 10^{1}$ & $1.8 \times 10^{-6}$ & $10^{4}$ \\
\hline
\end{tabular}

\footnotetext{
a. average projected Barnwell routine releases

b. maximum projected accidental releases assuming stack flow reduced from 110,000 SCFM to 60,000 SCFM.
} 
The routine release in Table 5 is reported to be measurable on the second range of the routine monitoring system which has a total range of six decades. This would indicate in the case of noble gas or plutonium releases that the routine monitor is of sufficient range to measure the accidental release.

Qualities of a good stack monitor have been discussed in other publications. $(2,3,35)$ The essential qualities are outlined briefly here.

- Sample withdrawal point is downstream from transitions, bends, etc., where velocity profile is stabilized.

- Multi-entry probe is provided to assure representative sample.

- Well-designed transport system is provided with short lines arranged and sized for minimum deposition.

- System has selectable warning level, gives audible and visual signal, and remains functional when challenged by the maximum release rates shown in Table 5 .

- Each system shail have an upper range of one decade above that required by the accident release rates shown in Table 5 .

- Failure of components is signaled at a control board.

- Warning system should be based upon rate of increase of activity, predetermined count rate, or accumulated count, if good discrimination against background is achieved.

- System needs to discriminate against naturally occurring airborne alpha emitters.

- System needs to have a minimum down time and be modular in construction with rapidly changeable components.

\section{VI.2.3.3 Stack Monitor Performance Criteria}

- Particulate radioactive material shall be removed by filters with effective pore size $\leq_{5} \mu \mathrm{m}$, having an efficiency of $\leq 99.5 \%$ for particles with diameters $\leq 0.3 \mu \mathrm{m}$. 
- A constant sample flow rate sha 11 be used and a constant displacement pump should be used as the air mover. An appropriately calibrated airflow meter shall continuously verify sample flow rate, and shall be accurate to within $\pm 20 \%$.

- The system shal1 be designed to remove, on a continuous basis, a representative sample.

- Particulate-generating gas phase reactions, corrosion, or release of contaminants should be absent downstream of the sampling point.

- When sampling a stack, the sample point shall be no less than 8 duct diameters and preferably should be at least 10 duct diameters downstream from any injection point or point of transition. A multientry probe shall be used for sampling in the duct or stack unless prior tests have shown concentrations to be uniform to $\pm 10 \%$ across the stack.

- Sampling conditions should approach isokinetic. The sampler inlet velocity to duct velocity ratio should be $1.0 \pm 0.2$.

- Sampling 1 ines shall be kept short. Where possible, the distance from sample point to collector should be less than 10 feet. Sample line bend radii shall exceed five sampling line diameters.

- The sample delivery system shall be corrosion resistant and designed for streamline flow with no right angles or sharp bends. Stainless steel should be used for construction, and plate out of radioactive materials should be less than $5 \%$.

- The range of detection capability shall overlap the range of stack monitoring instrumentation used for routine or non-emergency monitoring. (The emergency instrumentation and routine instrumentation may be the same.) 
- The entire system operation shall be put on routine maintenance, checked at least quarterly, and calibrated and maintained when indicated.

\section{VI.2.4 Environmental Air Monitoring}

Formulating a monitoring scheme to cope with an accident which results in the failure of the containment is difficult due to the great uncertainty associated with the mechanisms and conditions resulting from such an accident. Since the structure is designed to withstand the stresses imposed by most natural phenomena, the situation which results in a failure is highly abnormal or improbable. Information on the sequence of events, change of physical conditions, and behavior of components (such as enclosures and equipment) under such conditions is sparse. Thus, it is difficult even to conceive of the characteristics of the aerosol generated under these 111 defined conditions. The uncertainty about the size and location of the release add to the difficulty.

A monitoring system desirably should fulfill three functions: 1) alert those responsible that an event is occurring, 2) characterize the release so appropriate action can be taken and 3) accumulate material for a thorough "after-the-fact" evaluation. In a containment failure due to natural phenomena, meteorological instrumentation (discussed in a later section) and sensory observations will alert all individuals in the vicinity of the plant that an incident of concern is occurring. Failure of the containment should be readily apparent and lesser losses of integrity such as small invisible cracks will have less or no environmental consequences if the exhaust system remains functional. Thus, the alerting function is assumed to be adequately covered by existing, available instrumentation and personnel.

A sample/monitor can provide an early warning at an environmental point of interest. The alarm is necessarily delayed by the amount of time required for the material to travel from the release point to the instrument. However, such instrumentation provides only a measure of the concentration at the point of interest and not an easily relatable estimate of the total amount released. A sample/monitor could be of benefit for isolated points where atmospheric conditions, distance to the plant boundary, population mass, 
BNWL-1857

etc., warrant measurements. The number and choice of locations are dependent on several factors including size of site, analysis of accident potential, and terrain features. Logical locations might be site boundary, population center, and individual residence in potential direct path of a plume.

Data necessary to determine appropriate protective actions against an accidental release of airborne radioactive material resulting from containment failure of a fuel reprocessing facility are usually derived from an assumed release related to 1 ) facility and process parameters, the type of accident, and real time meteorological measurements, 2) measurement of the radioactive material inventory in the plume coupled with real time meteorological measurements, or 3) actual measurements of the parameter required, such as the concentration of airborne radioactive materials at the point of interest.

The use of remote area monitors for measuring ambient radiation fields in the environs also could be worth while. The ambient radiation field is produced by mixed fission products from fallout onto the ground or other horizontal surfaces. A distinct feature of the ambient radiation field is its unevenness, in part caused by terrain factors, vegetation and shielding from structures, as well as micrometeorological conditions. The radioactive cloud from either a burst or continuous release could result in a significant ambient field.

The characteristics of the ambient field in the environs is highly dependent on the specific location of the measurement as well as the time after the occurrence and the various fractions released. An appreciable fraction of the dose contribution may be from beta or low energy "nonpenetrating" photon radiation, and to adequately characterize this field, a thin-walled detector is required.

Once the direction of the plume and anticipated ground level concentrations of concern are calculated from available data, mobile units could be dispatched to critical locale by predetermined routes to intercept the path of the plume and aid in determining the airborne hazard. Personnel involved in such monitoring will undoubtedly be provided with respiratory 
protective equipment but the samples and detector need also to be protected from contamination in order to obtain as accurate an estimate of the radioactive release as possible. The interior of these monitoring vehicles can be made relatively air tight and equipped with HEPA filtered intakes and exhausts. These and possible other samples would then be available for "after-the-fact" evaluations.

\section{VI.2.4.1 Transportable Air Monitoring Systems}

Emergency monitoring of airborne radioactivity concentrations, if accomplished in the field, is often done with radiation monitoring instruments calibrated or otherwise used in conjunction with grab samples of ambient air. (36-39) A few air samplers with self-contained power supplies have been described which enable a sample of particulate radioactivity to be obtained in the field. (40-43) In addition, several self-contained air samplers of the "personal" type have been described. (44-49) However, essentially no wholly self-contained portable air or liquid radioactivity monitors have been designed for emergency purposes, with the possible exception of the survey meter adopted by Block and co-workers. $(40)$

Consideration of the potential applications and performance requirements leads to the conclusion that the concept which provides for the direct examination of an air filter with a portable survey meter could be adapted to direct monitoring of airborne radioactivity in the field. The survey meter should meet the requirements described in Section VI.2.2 and should be mechanically and otherwise compatible with the air sampler portion. Logically, the two parts should be designed to function as an integral unit but with provision made for detached, independent operation. Hence, each unit would have its own source of power.

The air mover-sampler will require considerably more power than other portable electronic instrumentation. The power requirement for an air sampling rate on the order of 20 liters per minute is several watts. since such power levels cannot be conveniently provided with $D$ cells, the use of $\mathrm{Ni}-\mathrm{Cd}$ wet cells or similar high efficiency-low weight batteries 
will be required. Rechargeable batteries are recommended, with provision for recharging from a standard $117 \mathrm{~V}, 60 \mathrm{~Hz} A C$ power source of a $12 \mathrm{~V} \mathrm{DC}$ automotive system.

The development of a ruggedized partially depleted diffused junction silicon detector ${ }^{(50)}$ and a ruggedized silicon surface barrier detector $(57)$ can provide the basis for a portable alpha air monitor although an adequate commercial unit does not presently exist. With a suitable air sampling medium and a collection rate of $0.5 \mathrm{cfm}$, a portable system could detect about $1 \times 10^{-11} \mathrm{\mu Ci} / \mathrm{cm}^{3}$. A sampling period of about 10 minutes would be required. The same system could easily be adapted to provide beta or gamma evaluation by substitution of a suitable detector or a second system devoted solely to measurement of beta or gamma or both simulataneously.

Al though the system could be stored in a control center and the vehicle used for other purposes, the system may not be used easily with any available vehicle since special power sources for the air mover and personnel protection devices would require a special vehicle. Radio communication should be available in the vehicle to report results as obtained to the control center and to enable the control center to direct the vehicle to points of interest.

The detection level of such a system depends upon the sampling flow rate, sampling time and counting time chosen. These parameters can be altered to attain the sensitivity needed for the incident under investigation.

Ambient radiation levels can also be measured by portable instruments adapted with appropriate detectors mounted outside the vehicle and provided with a simple chart recorder.

\section{VI.2.4.2 Environmental Air Monitor Performance Criteria}

The criteria listed here are in addition to those general criteria just presented.

- The system shall be designed to take a representative sample of the ambient air on a continuous basis. The preferred sampling location 
is at one meter above ground level in a location free from unusual micrometeorological or other conditions (e.g., proximity of large buildings, vehicular traffic) which could result in artificially high or low air concentrations.

- The sample collected should be easily measurable in place with portable monitoring instruments and removable for subsequent laboratory analysis.

- The measurement capability for particulate activity shall have a minimum range of $10^{-3}$ to $10^{-7} \mu \mathrm{Ci} / \mathrm{cm}^{3}$ gross al pha referenced to ${ }^{239} \mathrm{Pu}$ for 30 minute sample. This range shall overlap the range of instrumentation used for routine or nonemergency monitoring.

- The measurement capability for particulate activity shall have a minimum range of $10^{-1}$ to $10^{-6} \mu \mathrm{C} i / \mathrm{cm}^{3}$ gross beta-garma referenced to ${ }^{137}$ Cs for a 10 minute sample. This range shall overlap the range of instrumentation used for routine or nonemergency monitoring.

- The instrument system shall be protected from the external environment and should be housed in a locked facility to afford a measure of security from accidental or willful damage or tampering.

- The entire system operation shall be checked at least quarterly and calibrated and maintained when indicated.

- To simplify calibration, operation and interpretation, a fixed sampling rate of 10 to 30 liters per minute should be used. Sampling rate shall remain constant to within $\pm 25 \%$ during normal operation.

- The unit shall be compatible with membrane, glass fiber, cellulose fiber, and charcoal loaded filters commonly used for air sampling. The size of the filter used is dependent upon the size of the detector, but a $47 \mathrm{~mm}$ diameter should be considered. Filter diameter should not exceed $100 \mathrm{~mm}$.

- The filter material used shall have an efficiency of $99.5 \%$ or greater for particles $0.3 \mu \mathrm{m}$ in diameter.

- Air flow shall be continuously indicated by an appropriate clearly marked gage having an accuracy of $\pm 20 \%$. 
If a portable or mobile system, the following criteria apply:

- Power should be provided by wet cells which conform to the specifications put forth by the National Bureau of Standards.

- Battery lifetime should be greater than 8 hours under load.

- The sampling unit shall be provided with a battery test or other indicator of battery condition.

If a stationary fixed station, the following criterion applies:

- The system should be capable of operation on $117 \mathrm{~V} 60 \mathrm{~Hz} A C$ and should be unaffected by voltage or frequency changes of $\pm 20 \%$.

\section{VI.2.5 Personnel Dosimeters}

The determination and control of personnel external exposure or dose are of prime importance in a fue 1 reprocessing plant. A wide variety of devices integrate external exposure. For emergency purposes only those devices which provide for a direct, instantaneous readout without disturbing the operation of the device or the accumulation of information will be considered. Hence, for all practical purposes, photographic and luminescent devices are excluded. However, they should be utilized to determine the total external dose received during the emergency.

With the exclusion of photographic and luminescence systems, essentially only electronic methods remain. Pocket ionization chambers, survey meters with integration capability which are described in Section VI.2.2.1, and personal alarm dosimeters characterize this group.

Personal (or, alternatively) pocket alarm dosimeters are a hybrid pocket dosimeter and integrating survey meter. Several have been described in the open 1 iterature over the past few years. ${ }^{(52-57)}$ Made available primarily as a result of the development of miniature components, in many respects these have not realized their full potential. Nevertheless, they may be superior to either the pocket ionization chamber or integrating survey meter for rescue purposes. In general, these should meet the requirements described for integrating survey meters. 
Direct reading pocket ionization chambers have been used extensively during maintenance and other operations where frequent checks are required to control persorinel exposure and dose. Pocket ionization chambers are suitable for emergency and rescue situations although they have no alarm capability. Pocket ionization chambers should generally conform to the standards and criteria put forth by the American Standards Institute. (58)

\section{VI.2.5.1 Personnel Dosimeters Performance Criteria}

- The pocket ion chamber shall have a range of 0 to $200 \mathrm{R}$ if it is to be used for personnel involved in rescue work in which exposures to $100 \mathrm{R}$ may be incurred. If used for other purposes, such as protection of property, the range shall be appropriate to the maximum permitted exposure. The maximum permitted exposure shall be in the range of 40 to $70 \%$ of full scale of the pocket ionization chamber used.

- The instrument shall be provided with an optical system to permit direct readout. Major scale divisions shall be indicated by heavy lines at 0,50 and $100 \%$ of scale; the scale should be further subdivided into tenths and twentieths by progressively shorter and/or less bold lines.

- Leakage shall be $\leq 2 \%$ of full scale in a 24 hour period.

- Accuracy shall be $\pm 25 \%$ of the true exposure referenced to 20 to $80 \%$ of full scale exposure. Precision at any level shall be $\pm 10 \%$ at the $95 \%$ confidence level.

- Energy dependence shall be $\pm 10 \%$ for photons in the energy range $35 \mathrm{keV}$ to $1.3 \mathrm{MeV}$.

- The instrument system shall be unaffected by relative humidities from $40 \%$ to $95 \%$ over the temperature range of $60^{\circ} \mathrm{F}$ to $120^{\circ} \mathrm{F}$.

- For the operating temperature range, the temperature coefficient shall be $\pm 0.5 \%$ per ${ }^{\circ} \mathrm{C}$ and it should be $\pm 15 \%$ over the entire range.

- The unit shall be rate independent to $10^{4} \mathrm{R} / \mathrm{hr}$. 
- There shall be no deleterious effect to the system from radiofrequency field intensity of $1000 \mathrm{~V} / \mathrm{m}$, microwave exposure to $10 \mathrm{~mW} / \mathrm{cm}^{2}$, photon exposure to $5 \times 10^{5}$ referenced to the energy range between 0.8 to $1.2 \mathrm{MeV}$, and external electrostatic fields of $5 \mathrm{~V} / \mathrm{cm}$.

- The unit shall be unaffected by magnetic fields with intensities of 10 oersteds.

- The unit shall be able to withstand mechanical stress or shock equivalent to a drop from a height of 4 feet onto a hard surface; such a shock or stress shal1 not change or alter any reading more than $\pm 10 \%$ of full scale.

- Change in reading with spatial orientation shall be $\leq 3 \%$ of full scale.

- Angular dependence shall result in a reading of not less than $70 \%$ of the true reading for a specified energy when energy dependence is being evaluated.

- Sensitivity shall be $\leq 5 \%$ at midscale.

VI.2.5.2 Alarming Dosimeters

- A meter, digital register or other readout shall continually register the accumulated dose.

- The instrument sha11 weigh no more than 300 grams ( $10.5 \mathrm{oz}$ ).

- The instrument should be powered by any single or combination of commercially available alkaline type dry cells. Mercury cells, while acceptable, are discouraged. 


\section{VI.3 METEOROLOGICAL INSTRUMENTATION}

A meteorological monitoring program is an integral part of the emergency preparedness program at a fuel reprocessing plant. The meteorological data will be used in the determination of necessary actions in the event of an accident and in the conduct of post-accident evaluations. In view of this, the meteorological monitoring system shall be sufficient to evaluate the atmospheric processes involved in the transport, dilution, and depletion of any atmospheric release of consequence. The required data and associated data acquisition systems are discussed in the following sections.

\section{VI.3.1 Meteorological Data Requirements}

The meteorological data will be used to determine the transport and dispersion of a radioactive cloud by use of an atmospheric diffusion model. A brief review of common models for both continuous and semi-instantaneous sources is given in Table 6 .

The range of required instruments for the diffusion models is broad. The systems based on tower data require four variables: 1) air temperature $(T), 2)$ wind velocity $(\bar{u}), 3)$ standard deviation of the horizontal angular component of the wind vector $\left(\sigma_{\theta}\right)$ and 4$)$ the standard deviation of the vertical angular component of the wind vector $\left(\sigma_{\phi}\right)$.

A single "profile tower" instrumented to measure $\sigma_{\theta}, \sigma_{\phi}, T$ and $\bar{u}$ at multiple elevations will provide the data necessary for most models. In each of the models, the required data have been correlated to the standard deviation of plume spread, $\sigma_{y}$ and $\sigma_{z}$, which are the independent variables in applied diffusion models. Since the turbulent eddies of the atmosphere diffuse airborne material, it is more direct to correlate $\sigma_{y}$ and $\sigma_{z}$ to measured wind fluctuations than to secondary parameters such as stability. Such correlations have been demonstrated empirically to be high. (59-64) Hence, the instrumentation system for diffusion estimates may be significantly improved by including direct eddy measurements, which when added to the required temperature gradient measurements, enhance the overall system reliability. Thus, an independent sensor system is available in the event of questionable results or failure in the eddy measurement sensor. 
TABLE 6. Examples of Atmospheric Diffusion Models and Their Required Inputs

Technique

Required Data

Required Instrument References

Continuous Source (Plumes)

Hay-Pasquil (1959)

$\sigma_{\theta}, \sigma_{\phi}, \bar{u}$

Fast response bivane

Sutton's Model

$\frac{\partial T}{\partial z}, \quad \bar{u}$ anemometer

Vertical array of differential temperature sensors and anemometers

Pasquil's Curves (1958)

$\bar{u}$, solar radiation, $\%$ cloud cover

Visual estimates or

$$
\frac{\partial T}{\partial z}, \quad \frac{\partial \bar{u}}{\partial z}
$$

Vertical array of differential temperature sensors and anemometers

Hanford Model

$$
\sigma_{\theta}, \bar{u}, \frac{\partial T}{\partial z}
$$

Vertical array of differential temperature sensors and fast response vane anemometer

Tracking Neutrally

Balloon position, Time

Tracking radar, airborne radar transponder, tetroons

\section{Semi-Instantaneous Sources (Puffs)}

Smith-Hay (1961)

Cramer (1964)

Tracking Neutrally Buoyant Balloons

$$
\begin{aligned}
& \sigma_{\theta}, \sigma_{\phi}, \bar{u} \\
& \sigma_{\theta}, \bar{u}
\end{aligned}
$$

Balloon position, Time
Fast response bivane anemometer

Fast response vane anemometer

Tracking radar, airborne radar transponder, tetroons

\footnotetext{
$\sigma_{\theta}=\begin{aligned} & \text { standard deviation of lateral angular component of wind } \\ & \text { vector }\end{aligned}$

$\sigma_{\phi} \quad=$ standard deviation of vertical angular component of wind

$\frac{\partial T}{\partial z}=$ vertical temperature gradient

$\bar{u} \quad=$ mean wind speed
} 
Specific recommendations for equipment to record, process, and display data will depend upon the model(s) used and the requirements of the emergency plan. The obvious general requirements should include: 1) immediate access provided to summarized data for real-time or post-accident evaluation; 2) errors introduced by recording, processing and display equipment either be included in the data accuracy limits identified or be very small in comparison to the acceptable errors; and 3) all data be permanently recorded. Display of meteorological data at the emergency control center location will require real-time data transmission by an appropriate technique such as telemetry or telephone line.

If an onsite or offsite connection with a computer facility is available, consideration should be given to automatic data handling. Either digital or analog computers could be used. From the standpoint of response time and accuracy, as much automation as possible is desirable as a tool for, and not a replacement for, emergency personnel capable of using basic data to arrive at sound meteorological conclusions.

Calibration and maintenance requirements are dictated by the accuracy and reliability requirements for the data. Calibration of all calibration equipment should be traceable to appropriate national standards. Calibrations should include system end-to-end checks for the range of probable environmental conditions. As a minimum requirement, the entire meteorological system should be checked at least quarterly and calibrated and maintained as necessary.

The sensor system should be designed to meet the specified data and data accuracy criteria for the range of $c l$ imatological conditions at a particular site. A measurement of wind speed, direction, and direction variability should be available from at least at one level in the event of an accident. In regions frequented by hurricanes and/or tornadoes such assurance could be provided by establishing a mast and wind instrument set of rugged design at a point separated from both the facility and the profile tower. Instruments of rugged design are available which can withstand hurricane force winds. The redundancy and separation of a rugged wind set system make the probability of a tornado striking the facility, the profile tower, and the rugged wind instrument set highly improbable. 
For climatological extremes at some sites, it may be impractical to meet certain of the criteria established so individual site evaluations and judgments will be required.

\section{VI.3.2 Performance Criteria for Meteorological Systems}

- A meteorological profile tower shall be located near the fuel reprocessing plant for determining diffusion and transport of a plume.

- To permit determination of longer range plume trajectories, transport towers in the region outside of a facility boundary shall be installed either on a temporary or a permanent basis as local characteristics dictate the need.

- Tower location shall be representative of surrounding terrain and vegetation cover and shall be outside the influence of anomalous terrain or building effects.

- Meteorological instrumentation shall be located at a minimum of two tower diameters from outside of tower and shall be placed on the prevailing windward side of tower.

- Instruments sha11 be operable within the measurement accuracy prescribed over the norma 1 range of environmental conditions common to the region as indicated by long-term climatological records.

- At sites where it is impractical to meet these performance criteria during extreme conditions, provisions sha 11 be made to ensure measurements of wind speed, direction, and direction variability of at least one point during these extreme conditions.

- Recording, processing and display equipment errors either shall be included in data accuracy limits specified or shall be very smal1 when compared to specified limits of the instrumentation.

- Readout capability shall be provided at or near the instrument and at a central process control station designated as the emergency control center. 
- The entire meteorological system shall be checked at least quarterly and calibrated and maintained when indicated.

- The mean time to failure shall be 2 years.

- At 60 meters above the local roughness elements or at the maximum height of a potential release, if greater than 60 meters, measurements shall be made of wind speed, wind direction, lateral wind direction variability $\left(\sigma_{\theta}\right)$. Temperature and measurements should be made of vertical wind direction variability $\left(\sigma_{\phi}\right.$ or $\left.\sigma_{w}\right)$.

- At 9 to 15 meters above the local roughness elements, measurements shall be made of wind speed, wind direction, lateral wind direction variability $\left(\sigma_{\theta}\right)$, and temperature. A duplicate set of wind instruments should be installed at the 9 to 15 meter level to provide unaffected data when the main instrument set is in the wake of the tower.

- At 2 meters above the local roughness elements, measurements shall be made of wind speed, wind direction, lateral wind variability $\left(\sigma_{\theta}\right)$, and temperature.

- A surface measurement of precipitation suitable for determining precipitation rate during an accident should be made.

- Accuracy of the meteorological measurements shall be as follows with time averages assumed to be over periods ranging from 15 minutes to 1 hour:

- Average wind speed: $\pm 0.25 \mathrm{miles}$ per hour (mph) or $\pm 2 \%$.

- Average wind direction: \pm 5 degrees.

- Starting speed for wind speed and direction: $\leq 2 \mathrm{mph}$.

- Mean temperature: $\pm 7^{\circ} \mathrm{F}$.

- Mean temperature difference between heights: $\pm 0.1^{\circ} \mathrm{F}$.

- Lateral wind direction variability $\left(\sigma_{\theta}\right): \pm 20 \%$ (e.g., a vane with a natural wave length of approximately 15 meters or less and a damping ratio of approximately 0.6 ). 
- Vertical wind direction variability $\left(\sigma_{\phi}\right.$ or $\left.\sigma_{w}\right): \pm 35 \%$ (e.g., a propeller with a distance constant of approximately 1.5 meters or less).

- Errors due to tower influences shall be added to the above uncertainties to determine total errors. The above accuracy limits shall include sensor processing and display errors.

- Wind speed and direction data shall be measured at a height of 15 to 30 meters above local roughness elements. 


\section{REFERENCES}

1. Selby, J. M. and C. M. Unruh, Technological Considerations in Emergency Instrumentation Preparedness, Phase I - Current Capabilities Study, BNWL-1552, Battel1e-Northwest, Richland, WA, January 1971.

2. Selby, J. M., B. V. Andersen, L. A. Carter, J. P. Corley, C. E. Elderkin, R. L. Kathren, L. C. Schwendiman, C. M. Unruh, E. C. Watson and R. K. Woodruff, Technological Considerations in Emergency Instrumentation Preparedness, Phase II-A (Reactors), BNWL-1635, Battelle-Northwest, Richland, WA, May 1972.

3. Selby, J. M., B. V. Andersen, L. A. Carter, J. P. Corley, J. G. Droppo, C. E. Elderkin, J. Mishima, L. C. Schwendiman, C. M. Unruh, E. C. Watson, L. D. Williams and R. K. Woodruff, Technological Considerations in Emergency Instrumentation Preparedness, Phase II-B (Mixed Oxide Fuel Fabrication Facilities), BNWL-1742, Battelle-Northwest, Richland, WA, Apri1 1973.

4. Federal Register, 36 FR 22851, December 1, 1971.

5. Safety Analysis Report - Midwest Fuel Recovery Plant, NED0-10178, General Electric Co., San Jose, CA, December 1970.

6. Safety Analysis Report - Barnwell Nuclear Fuel Plant, Allied Chemical Company.

7. Environmental Report - NFS Reprocessing Plant Docket Number 50-201, Nuclear Fuels Services, Inc., Rockville, MD, 1973.

8. The Safety of Nuclear Powered Reactors (Light Water-Cooled) and Related Facilities, USAEC, WASH-1250, July 1973.

9. Stratton, W. R., A Review of Criticality Incidents, USAEC Report LA-DC-6551, Los ATamos Scientific Laboratory, 1964; also A. D. Callihan, Oak Ridge National Laboratory, private communication, April 1966.

10. U. S. Atomic Energy Commission, Division of Operational Safety, Operational Accidents and Radiation Exposure Experience Within the United States Atomic Energy Commission, 1943-1967, U. S. Government Printing Office, Washington, December 1968.

11. ORNL Staff, Siting of Fuel Reprocessing Plants and Waste Management Facilities, ORNL-4451, Oak Ridge National Laboratory, Oak Ridge, TN, JuTy 1970. 
12. Selby, J. M., E. C. Watson, J. P. Corley, D. A. Waite, L. A. Carter, J. G. Droppo, R. G. Clark, C. L. Brown, L. D. Williams, R. J. Hall, L. C. Schwendiman, J. Michima, R. K. Woodruff, T. I. McSweeney and J. B. Burnham, Considerations in the Assessment of the Consequences of Effluents from Mixed Oxide Fuel Fabrication Plants, BNWL-1697, Battelle-Northwest, Richland, WA, June 1973.

13. Michima, J., L. C. Schwendiman, and C. A. Radasch, Plutonium Release Studies, IV. Fractional Release from Heating Plutonium Nitrate Solutions in a Flowing Air Stream, BNWL-931, Battelle-Northwest, Richland, Washington, November, 1968.

14. Mishima, J. and L. C. Schwendiman, Interim Report: The Fractional Airborne Release of Dissolved Radioactive Materials During the Combustion of 30 Percent Normal Tributyl Phosphate in 4 Kerosine Type Dilvent, BNWL-B-274, Battelle-Northwest, Richland, WA, June 1973.

15. J. L. Sutter, J. Mishima, and L. C. Schwendiman, Fractional Airborne Release of Strontium During the Combustion of 30 Percent Normal Tributyl Phosphate in a Kerosine Type Diluent, BNWL-B-358, BattelleNorthwest, Richland, WA 99352, June 1974.

16. Dickerson, M. H., J. B. Knox, J. J. Cohen and R. C. Orphan, A Concept for an Atmospheric Release Advisory Capability, UCRL-51656, Lawrence Livermore Laboratory, University of California, Livermore, CA, September 24, 1974.

17. Briggs, G. A., Plume Rise, AEC Critical Review Series, USAEC, 1969.

18. Allen, Robert E., Radiation Surveillance Networks, WASH-1148, 1969.

19 Wilson, R. H., A Method for Immediate Detection of High Level Neutron Exposure by Measurement of Sodium-24 in Humans, HW-73891, 1962.

20. Criticality Accident Alarm System, American National Standard, N16.2, 1969 .

21. Aspina11, K. J., "Criticality Detection and Alarm Systems," Nuclear Engineering, March 1966.

22. Tyree, W. H., A Neutron Criticality Detection System RFP-1621, March 21, 1972 .

23. Aspinall, K. J., J. T. Daniels, Review of U.K.A.E.A. Criticality Detection and Alarm Systems 1963/64. Part I: Provision and Design Principles, AHSB-S-R-92, 1965.

24. Immediate Evacuation Signal for Use in Industrial Installations Where Radiation Exposure May Occur, American National Standard, N2.3, 1967. 
25. Friend, P. C., Technical Manual for Neutron Sensitive Criticality Detector, BNWL-MA-29, May 16, 1966.

26. Costre11, L., Standard Nuclear Instrument Modules, TID-20893, Rev. 2, January 1968; also Rev. 3, 1969.

27. Zuerner, L. V. and R. L. Kathren, Evaluation Program for Portable Radiation Monitoring Instruments, BNWL-SA-1947, 1968; cf. also Health Physics Operational Monitoring, C. A. Willis and J. Handloser, Eds., vol. 2, Gordon and Breach, New York, 1971.

28. Unruh, C. M., "Methods of Measurement and Interpretation of Results in Radiation Monitoring and Dosimetry," in Radiation Protection Monitoring Proc. Symp. Bombay, December 9-13, 1968, pp. 123-147, 1969.

29. Specifications for Dry Cells and Batteries, National Bureau of Standards Handbook 71, U.S. Government Printing Office, Washington, DC, 1962.

30. Schmidt, C. T. and J. J. Koch, "Plutonium Survey with X-Ray Detectors," Hazards Control Progress Report No. 26, Lawrence Radiation Laboratory, University of California, Livermore, CA.

31. Tinney, J. F. and J. J. Koch, An X-Ray Survey Meter for Plutonium Contamination, UCRL-50007-67-3, N.C. \#29.

32. Lindeken, C. L. and J. J. Koch, Optimization Studies for the FIDLER Detector, UCRL-50007-68-2, \#31.

33. Tinney, J. F. and T. 0. Hoeger, Overburden Attenuation Measurements for 239Pu-241Am Using the FIDLER Detector, UCRL-50007-69, \#35.

34. Stuart, T. P., Use of Aerial Surveys for Determining Plutonium Concentration, CONF-710401, EG\&G, Inc., Las Vegas, NV, Apri1 1971.

35. Guide to Sampling Airborne Radioactive Materials in Nuclear Facilities, American Nationa 1 Standard N13.1, 1969.

36. "Environmental Monitoring in Emergency Situations," IAEA Safety Series No. 18, IAEA, Vienna, 1966.

37. Howells, H. and H. J. Dunster, "Environmental Monitoring in Emergencies," Environmental Surveillance in the Vicinity of Nuclear Facilities, Proc. Symp., Charles C. Thomas, Springfield, IL, pp. 151-161, 1970.

38. Tait, G. W. C. and W. F. Merritt, "Emergency Radiation Monitoring of Drinking Water," Health Physics, vol. 1, p. 164, 1958.

39. Brodsky, A. and G. V. Beard (Eds.), A Compendium of Information for Use in Controlling Radiation Emergencies, TID-8206, 1960. 
40. Block, S. and E. L. Beard, "Converting a Portable Survey Meter's Ion Chamber into a Continuous Air Mon tor by a Simple Expedient," in Hazards Control Quarterly Report No. 22, UCRL-14534, pp. 32-40, JuTy-September 1965.

41. Block, S., E. L. Beard and 0. Barlow, "A Portable Continuous Air Monitor for Field or Laboratory Use," in Hazards Control Progress Report No. 21, UCRL-14351, pp. 1-9, Apri1-June 1965.

42. Cohen, J. J. and R. D. Taylor, "Development of a Lightweight Portable 'Hi-Vol' Air Sampler," in Hazards Control Progress Report No. 28, UCRL-50007-67-2, pp. 19-20, May-August, 1967.

43. Stoddard, D. H., "Emergency Air Sampler," Health Phys., vol. 11, p. 320, 1965.

44. Bloor, W. A., R. E. Eardley and A. Dinsdale, "A Gravimetric Personal Dust Sampler," Ann. Occup. Hygiene, vol. 11, p. 81, 1968.

45. Higgins, R. I. and P. Dewel1, "A Gravimetric Size-Selecting Personal Dust Sampler," in Inhaled Particles and Vapours, C. N. Davies, Ed., vol. 2, pp. 575-583, Pergamon Press, 0xford, 1967.

46. Ingram, W. T., "Personal Air-Pollution Monitoring Devices," Am. Ind. Hyg. Assn. J., vol. 25, p. 298, 1964.

47. Lindekin, C. L. and R. D. Taylor, "Battery-Operated Staplex Sampler," Am. Ind. Hyg. Assn. J., vo1. 26, p. 322, 1965.

48. Sherwood, R. J. and D. M. S. Greenha 1gh, "A Personal Air Sampler," Ann. Occup. Hyg., vol. 2, p. 127, 1960.

49. Block, S., E. L. Beard and A. H. Forsman, A Personal Air Sampler for Atmospheric Contamination, UCRL-6192, 1961 .

50. Data Sheet - "Diffused Junction Silicon Radiation Detectors," Model DJC-400-50-100, The Harshaw Chemical Company, Solon, OH, January 1973.

51. Data Sheet - "R Series Ruggedized Silicon Surface Barrier Detector" Ortee Incorporated, Oak Ridge, TN, November 1972.

52. Allendew, D. and I. W. Collip, "A Personal - Radiation Monitor with Audible Warning Device," J. Sci. Inst., vol. 33, p. 120, 1965.

53. Brown, D. P., "A Pocket-Size, Signaling, Radiation Dosimeter," Health Physics, vol. 12, p. 943, 1966.

54. Erickson, G. L., A Selectable Level Pocket Dose Rate Alarm Dosimeter, DUN-5938, 1969; cf. also New Rate and Integrating Personal Alarm Dosimeter Designs, DUN-SA-130, 1970. 
55. Jones, A. R., "A Miniature Warning Dosimeter," Health Physics, vo1. 11, p. 363,1967 .

56. Lakin, R., A Persorinel Radiation Dosimeter with Storage for Preset Alarm and Continuous Readout, UCRL-14925-T, October 17, 1965; presented before 13th Annual Nuclear Science Symposium, Boston, MA; cf. also UCRL-14534, pp. 28-31, 1965.

57. Tanaka, E., "A Personal Radiation Alarm Dosimeter," Health Physics, vol. 13, p. 1337, 1967.

58. Performance Specifications for Direct Reading and Indirect Reading Pocket For X- and Gamma Radiation, American National Standard N13.5, 1972.

59. Slade, D. N., Meteorology and Atomic Energy, TID-24190, July 1968.

60. Hay, J. S. and F. Pasqui1, "Diffusion from a Continuous Source in Relation to the Spectrum and Scale of Turbulence," Advances in Geophysics, vol. 6, pp. 345-365, F. N. Frenkiel and P. A. Sheppard (Eds.), Academic Press Inc., NY, 1959.

61. Cramer, H. E., "A Practical Method for Estimating the Dispersal of Atmospheric Contaminants," Proceedings of the First National Conference on Applied Meteorology, pp. C-33 to C-55, American Meteorological Society, Hartford, CT, October 1957.

62. Cramer, H. E:, "A Brief Survey of the Meteorological Aspects of Atmospheric Pollution," BAM, vol. 40, p. 165, 1959.

63. Cramer, H. E., "Engineering Estimates of Atmospheric Dispersal Capacity," J. Am. Ind. Hyg. Assoc., vol. 20, p. 183, 1959.

64. Sutton, 0. G., "A Theory of Eddy Diffusion in the Atmosphere," Proc. Royal Soc. (London), Series A, vol. 135, p. 143, 1932.

65. Pasqui11, F., Atmospheric Diffusion, D. Van Nostrand Company, Ltd., London, 1962.

66. Pasquill, F. and F. B. Smith, "The Physical and Meteorological Basis for the Estimation of the Dispersion," Presentation at Second International Clean Air Congress of the International Union of Air Pollution Prevention Assoc., December 6-11, 1970, Washington DC, 1970.

67. Smith, F. B. and J. S. Hay, "The Expansion of Clusters of Particles in the Atmosphere," Quart. J. Roy. Meteorol. Soc., vol. 87, p. 82, 1961 .

68. Cramer, H. E., et. a1., Meteorological Prediction Techniques and Data System, Report GCA-64-3-G, 1964 . 


\section{DISTRIBUTION}

No. of

Copies

OFFSITE

A. A. Churm

ERDA Chicago Operations Office

Director Patent Division 9800 South Cass Avenue

Argonne, IL 60439

NRC Advisory Committee on Reactor Safeguards Washington, DC 20555

J. L. Liverman

ERDA Division of Biomedical and Environmental Research Washington, DC 20545

B. P. Brown

ERDA Division of Safety

Standards and Compliance Washington, DC 20545

30 E. J. Vallario ERDA Division of Safety Standards and Compliance Washington, DC 20545

10 E. K. Loop

ERDA Division of Safety Standards and Compliance Washington, DC 20545

Major General J. K. Bratton, USA

ERDA Division of Military Applications

Washington, DC 20545

M. B. Biles

ERDA Division of Safety

Standards and Compliance Washington, DC 20545
No. of

Copies

D. E. Patterson

ERDA Division of Safety

Standards and Compliance

washington, DC 20545

F. P. Baranowski

ERDA Division of Nuclear Fuel

Cycle and Production

washington, DC 20545

G. B. Pleat

ERDA Division of Nuclear Fuel

Cycle and Production

Washington, DC 20545

Admiral H. G. Rickover, USN

ERDA Division of Naval Reactors

Washington, DC 20545

H. Hollister

ERDA Division of Environmental

Control

Washington, DC 20545

C. Jackson

ERDA San Francisco Operations Office

133 Broadway

Wells Fargo Building

Oakland, CA 94616

J. R. Horan

ERDA, Idaho Operations

Commission

550 Second Street

Idaho Falls, ID 83407

R. E. Tiller

ERDA, Idaho Operations

Commission

550 Second Street

Idaho Falls, ID 83401 
No. of

Copies

D. M. Gardiner

ERDA, Chicago Operations Office

9800 South Cass Avenue

Argonne, IL 60439

R. Moser

ERDA, Chicago Operations Office

9800 South Cass Avenue

Argonne, IL 60439

D. W. Hendricks

ERDA, Nevada Operations

Office

P.0. Box 14100

Las Vegas, NV 89114

R. L. Hitechew

ERDA, Nevada Operations Office

P.0. Box 14100

Las Vegas, NV 89114

A. Whitman

ERDA, Nevada Operations Office

P.0. Box 14100

Las Vegas, NV 89114

J. R. Roeder

ERDA, Albuquerque Operations Office

P.0. Box 5400

Albuquerque, NM 87115

G. H. Harris

ERDA, Schenectady

Naval Reactors Office

P.0. Box 1069

Schenectady, NY 12301

T. M. Schoenberg

ERDA, Schenectady

Naval Reactors office

P.0. Box 1069

Schenectady, NY 12301
No. of

Copies

W. Reese

ERDA Savannah River

Operations Office

P.0. Box A

Aiken, SC 29801

B. Morgan

ERDA Savannah River Operations Office

P.0. Box A

Aiken, SC 29801

J. A. Lenhard

ERDA, Oak Ridge Operations Office

P.0. Box E

Oak Ridge, TN 37830

W. Johnson

ERDA, Oak Ridge Operations Office

P.0. Box E

Oak Ridge, TN 37830

27 ERDA Technical Information Center

W. COOl

NRC

Washington, DC 20545

D. Smith

Environmental Protection Agency

Washington, DC 20460

J. W. McCasl in

INEL, Aerojet Nuclear

550 Second Street

Idaho Falls, ID 83401

E. D. Graham

Argonne National Laboratory

P.0. Box 2528

Idaho Falls, ID 83401 
No. of

Copies

C. A. DeLorenzo

Argonne National Laboratory

9700 South Cass Avenue

Argonne, IL 60439

C. B. Meinhold

Brookhaven National Laboratory

Upton, Long Island, NY 11973

R. C. Yoder

Rockwell International

P.0. Box 888

Golden, C0 80401

C. M. Patterson

E. I. DuPont de Nemours and Company

Savannah River Plant

Aiken, SC 29801

C. L. Karl

National Lead Company of Ohio

P.0. Box 39158

Cincinnati, $\mathrm{OH} \quad 45239$
No. of

Copies

J. L. 01sen

University of California

Lawrence Livermore

Laboratory

P.0. Box 808

Livermore, CA 94550

J. F. Tinney

University of California

Lawrence Livermore

Laboratory

P.0. Box 808

Livermore, CA 94550

R. H. Thomas

University of California

Lawrence Berkeley

Laboratory

Berkeley, CA 94720

J. N.P. Lawrence

University of California

Los Alamos Scientific Laboratory

P.0. Box 1663

Los Alamos, NM 87544

A. M. Weinberg

Oak Ridge National Laboratory

Oak Ridge Operations Office

P.0. Box $X$

Oak Ridge, TN 37830

3 ERDA Richland Operations Office

R. L. Kathren

Portland General Electric

621 S.W. Alder

Portland, OR 97205

R. G. Jordan

Union Carbide Corporation

ORGDP-R-25

P.0. Box $P$

Oak Ridge, TN 37830

P. G. Holsted

B. J. Melton

P. R. Rhodes

Atlantic Richfield Hanford Company

G. C. Owens

United Nuclear Industries, Inc.

T. E. Dabrowski

2 Westinghouse Hanford Company

R. 0. Budd

G. D. Carpenter 
No. of

Copies

\section{Battelle-Northwest}

T. W. Ambrose

B. V. Andersen

W. J. Bair

L. A. Carter

J. P. Corley

J. G. Droppo

C. E. Elderkin

D. F. Fleming

J. J. Fuquay

A. J. Haverfield

K. R. Heid

J. J. Jech

H. V. Larson

S. Marks

W. D. Richmond

L. C. Schwendiman

J. M. Selby (100)

R. I. Smith

C. M. Unruh

D. A. Waite

E. C. Watson

L. D. Williams

Technical Information (5)

Technical Publications 